\title{
Can we 'seize' the gut microbiota to treat epilepsy?
}

Carmen De Caro ${ }^{\S, 1}$, Luigi Francesco Iannone ${ }^{\S, 1}$, Rita Citraro ${ }^{1}$, Pasquale Striano $^{2}$, Giovambattista De Sarro $^{1}$, Andrew Constanti ${ }^{3}$, John F. Cryan ${ }^{4,5}$ and Emilio Russo ${ }^{*}, 1$

${ }^{1}$ Science of Health Department, School of Medicine, University Magna Graecia, Catanzaro, Italy; ${ }^{2}$ Paediatric Neurology and Muscular Diseases Unit, DINOGMI-Department of Neurosciences, Rehabilitation, Ophthalmology, Genetics, Maternal and Child Health, University of Genoa, IRCCS "G. Gaslini" Institute, Genova, Italy; ${ }^{3}$ Department of Pharmacology, UCL School of Pharmacy, 29/39 Brunswick Square, London; ${ }^{4}$ UK.APC Microbiome Ireland, University College Cork, Cork, Ireland; ${ }^{5}$ Department of Anatomy and Neuroscience, University College Cork, Cork, Ireland.

Running title: Gut-microbiota and Epilepsy

${ }^{\S}$ Equally contributed

\section{*Author for correspondence:}

Prof. Emilio Russo, MD, Ph.D.

Department of Science of Health, School of Medicine and Surgery, University of Catanzaro;

Viale Europa - Germaneto 88100 Catanzaro, ITALY.

Phone +39 0961 3697397/Fax: +39 0961 3694192; e-mail: erusso@unicz.it

ORCID: 0000-0002-1279-8123 


\begin{abstract}
The gut-microbiota, the complex intestinal microbial ecosystem essential to health, is an emerging concept in medicine. Several studies demonstrate a microbiota-gut-brain bidirectional connection via neural, endocrine, metabolic and immune pathways. Accordingly, the gut microbiota has a crucial role in modulating intestinal permeability, to alter local/peripheral immune responses and in production of essential metabolites and neurotransmitters. Its alterations may consequently influence all these pathways that contribute to neuronal hyper-excitability and mirrored neuroinflammation in epilepsy and similarly other neurological conditions. Indeed, pre- and clinical studies support the role of the microbiome in pathogenesis, seizure modulation and responses to treatment in epilepsy. Up to now, researchers have focussed attention above all on the brain to develop antiepileptic treatments, but considering the microbiome, could extend our possibilities for developing novel therapies in the future. We provide here a comprehensive overview of the available data on the potential role of gut microbiota in the physiopathology and therapy of epilepsy and the supposed underlying mechanisms.
\end{abstract}

Keywords: Microbiota; Microbiome; Epilepsy; Inflammation; Microbiota-Gut-Brain-axis; Ketogenic Diet 


\section{Introduction}

More than 65 million people worldwide are affected by epilepsy, "a heterogeneous group of neurological diseases characterized by an enduring predisposition to generate epileptic seizures", according to International League Against Epilepsy (ILAE) definition (Fisher et al., 2014, 2005). The modifications occurring during epileptogenesis are still largely unknown but seem to include neural network reorganization, neurogenesis, neuroinflammation, an aberrant release of neurotransmitters, axonal sprouting and cell death (Pitkänen et al., 2015; Terrone et al., 2016). Furthermore, 30\% of patients with epilepsy are refractory to conventional antiepileptic drugs, representing an unmet need for epilepsy research from many possible points of view such as new treatments, biomarkers and so on (Chen et al., 2017). Recently, there has been increasing focus on the role of peripheral inputs (stimuli) that can interfere with neurodevelopment (De Vadder et al., 2014; den Heijer et al., 2018; Riazi et al., 2010; Spiller et al., 2005; Vieira et al., 2016) and be thus possibly involved in epileptogenesis and epilepsy.

In tandem there is a growing realization of the role of the gut-microbiota, a complex group of symbiotic microorganisms colonizing the gastrointestinal tract, in many aspects of brain and behaviour (Cryan and Dinan, 2012; Sherwin et al., 2018). Moreover, the microbiota is well poised to be a major source of these peripheral stimuli (Ma et al., 2019). Thus, the gut microbiota could play a role in epilepsy and might be a target for drugs therapy or be suitable as a biomarker.

To note, already at the beginning of XX century, some researchers have proposed the role of a gut microorganism (known as Bacillus epilepticus) in epilepsy pathogenesis, supposing that constipation and epilepsy could be correlated through this specific bacillus (Reed, 1916).

However, only in the last two decades, due to the progress in sequencing technology that allowed indepth investigations into the microbiota composition, connections and its metabolic potential, the underlying and bidirectional connections between the microbiota and brain has been extensively investigated. This link is globally named the microbiota-gut-brain (MGB) axis, including neural, 
endocrine, metabolic and immune system/pathways. Intestinal microbes of different areas of the gastrointestinal tract contribute to the central nervous system (CNS) development (e.g. neurogenesis, microglia maturation and myelination) (Erny et al., 2015a; Hoban et al., 2016), functions (e.g. cognition, mood and behaviour)(Clarke et al., 2013; Heijtz et al., 2011), and can also influence pathogenesis and progression of local and systemic diseases including several brain disorders (e.g. Parkinson's and Alzheimer's diseases, schizophrenia, autism spectrum disorder and multiple sclerosis) (Iannone et al., 2019; $\mathrm{Wu}$ and $\mathrm{Wu}, 2012$ ). On the other hand, it is known that in CNS neurodegenerative diseases, alterations of the MGB axis may lead to enteric inflammatory conditions and gastrointestinal dysfunctions, therefore impacting on gut microbiota (Rao and Gershon, 2016). According to recent animal and clinical studies, the gut-microbiome complex may also play a role in epilepsy and epileptogenesis; however, the precise mechanisms involved and their relevance are poorly understood. We provide here a comprehensive overview of the available data on the potential role of gut microbiota in the physiopathology and therapy of epilepsy and the supposed underlying mechanisms.

\section{Overview on gut microbiota}

The human gut-microbiota is constituted by an estimated $10^{8}-10^{11}$ cells of $\sim 1000$ different species (Sender et al., 2016), that live symbiotically with the host and fulfil substantial immunological, metabolic and protective functions in the healthy individual. Two bacterial phyla dominate its composition: Firmicutes and Bacteroides, followed by Actinobacteria, Proteobacteria and Verrucomicrobia (Qin et al., 2010). In addition to mainly anaerobic bacteria, also viruses, protozoa, archaea, and fungi are included in this environment, contributing to its equilibrium (Hugon et al., 2015; Richard and Sokol, 2019).

The composition of the gut microbiota is dynamic and there are temporary (also diurnal oscillations corresponding to sleep-wake and feeding-fasting cycles) (Liang et al., 2015; Zarrinpar et al., 2014) and dietary modifications (i.e. major alterations in diet composition or food quantities) (Healey et al., 
2017). New-borns receive the initial microbiome from their mothers characterized, in the early postnatal period, by low diversity and a relative dominance of the phyla Actinobacteria and Proteobacteria (Mueller et al., 2015). From the end of $1^{\text {st }}$ year of age onwards, the infants form a complex gut microbiome like adults (Rodríguez et al., 2015a; Yatsunenko et al., 2012a). A variety of factors such as exposure to antibiotics, infant feeding patterns, perinatal stress, infection, prematurity and mode of delivery (vaginal vs C-section) can alter gut microbiota composition (Borre et al., 2014). There is growing appreciation of the physiological consequences of such alterations and that they may represent a risk factor for development of psychiatric disorders in adulthood (Yang et al., 2016) or other brain diseases (Rodríguez et al., 2015b).

Also in adulthood, the gut microbiota is influenced by various factors including aging, diet, drugs, infections, and antibiotic treatments and thereby may have a deleterious effect on the host Yatsunenko et al., 2012). Indeed, a change in the gut-microbiota composition may have a role in the gradual activation of the immune system and consequently inflammation (Prenderville et al., 2015), probably via an impact on intestinal permeability, and neurosensory pathways (Ohland and MacNaughton, 2010; Shifrin et al., 2012). Finally, in the elderly, the composition of the gut microbiota is correlated with health outcomes (e.g. co-morbidity and fragility) and presents greater inter-individual variation than that of young adults (Claesson et al., 2012).

Commensal bacteria play different important functions in the gut, such as: maintaining the integrity of the intestinal barrier; stimulating intestinal epithelial cell regeneration; producing mucus and nourishing the intestinal mucosa by producing short chain fatty acids (SCFAs) (Round and Mazmanian, 2009). Whereas the role of sympathetic innervation in the modulation of gastrointestinal function is well known (e.g. gut peristalsis, sensory and secretion functions, reviewed in (Furness, 2007), several pieces of evidence suggest that various inputs from the gut, including those generated by microbiota, may influence the CNS in a complex bidirectional network (Mayer, 2011). Therefore, 
characterizing the gut-microbiota and its interactions with the host (mainly the connections with the CNS and gut via the MGB axis), may be necessary to better understand the homeostatic mechanisms and the pathogenesis of several diseases.

\subsection{Diet and the microbiome}

The diet, among all the factors which influence the composition of the gut microbiota, it is probably the most significant (Stanton et al., 2016). Indeed, change in dietary pattern, also with short duration, can shape considerably and reproducibly the gut microbiota composition (David et al., 2014). For example, a classic Western diet (rich in fats or proteins) significantly reduce beneficial butyrateproducing bacteria, Bifidobacteria and Eubacterium (Russell et al., 2011); a shift to a diet rich in fibres and prebiotics can restore these bacteria abundances (Cani et al., 2007). Generally, diets can modify in different way the gut microbiota and specific nutrients (as probiotics, protein, fats, digestible and non-digestible carbohydrates) could induce modification in particular gut microbial populations with secondary effects on host 'health (Singh et al., 2017).

Growing evidence have shown how the diet, through the gut microbiota, influences stress, behaviour and cognition and nutrition is already a complementary and alternative approach in several neuropsychiatric diseases (Sarris et al., 2015). In patients with psychiatric disorders a Mediterranean style diet is advisable (Del Chierico et al., 2014; Sánchez-Villegas et al., 2006) and the ketogenic diet (KD), discussed below, is extensively used in drug-resistant epilepsy, as well as other systemic and neurological disorders (e.g. multiple sclerosis, autism spectrum disorders) (Wheless, 2008).

\section{Microbiota-gut-brain axis and epilepsy: overlapping pathways?}

There is increasing evidence that the MGB axis is not mono-directional, but that brain and gut produce signals influencing each other to coordinate functions in health and disease (Dinan and Cryan, 2017). The gut-microbiota complex may be involved in epilepsy and epileptogenesis by mediating the proexcitatory effect of peripheral inflammation through immune system activation (e.g. release of 
inflammatory cytokines and chemokines), modulating neural networks by production of neurotransmitters (especially serotonin [5-HT], $\gamma$-aminobutyric acid [GABA] and glutamate), SCFAs and key dietary amino acids (e.g. tryptophan [TRP] and its metabolites) and acting consequently on the excitation and inhibition (E/I) balance. Moreover, the gut-microbiota can act through the dysregulation of the endocannabinoid system (ECS), the permeability of the gut barrier (with increase in lipopolysaccharide [LPS] levels) and by altering neuroendocrine (hypothalamic-pituitary-adrenal [HPA] axis) and neural (e.g. vagus afferents, enteric nervous system) pathways, as summarized in Figure 1 (Erny et al., 2015a; Foster and McVey Neufeld, 2013; Mayer et al., 2015; Rousseaux et al., 2007; Sharon et al., 2016).

Accordingly, multiple and not yet completely understood mechanisms are involved in this bidirectional communication and, although alterations in the gut microbiota and the epileptic process have not been directly studied, the nature of these connections suggest their potential significance to seizures, epilepsy and epileptogenesis. In this section, we provide an overview of these pathways and their possible link with epilepsy.

\subsection{Immunity and inflammation}

A massive and varied presence of microorganisms in the intestine needs the presence of physical barriers and continence systems to preserve the balance between microbes and host cells (Jandhyala et al., 2015). The intestinal immune system is mainly represented by the gut-associated lymphoid tissue (GALT), that represents $70 \%$ of the human body's immune system and $80 \%$ of the plasma cells producing immunoglobulin A. Lymphocytes $\mathrm{T}$ cytotoxic $\mathrm{CD}^{+}$and $\mathrm{T}$ helper (Th) $\mathrm{CD}^{+}$are the most represented immune cells in the epithelial layer further than mast cells, macrophages, antigen presenting cells and plasma cells (Mowat and Agace, 2014).

The resident cells of the innate immune system limit the impact of the gut-microbiota and protect enterocytes; on the other hand, intestinal bacteria can control and modify the differentiation and functions of the immune cells, not only in the intestine but also systemically (Rooks and Garrett, 
2016). Indeed, germ-free (GF) mice showed immune abnormalities, impaired antibody responses, failure of lymphoid development, a decreased population of $\mathrm{T}$ and $\mathrm{B}$ cells and reduced production of cytokines (Smith et al., 2007).

Commensal gut microbiota is mainly recognized by pattern recognition receptors (PRRs) and specifically by toll-like receptors (TLRs). Microorganisms have a conserved and unique pattern that can activate TLRs with the start of two responses: an immune pro-inflammatory response with production of cytokines mediated by the myeloid differentiation primary response gene 88 (MyD88), or the induction of tolerance mechanisms through TIR-domain-containing adapter-inducing interferon- $\beta$ (TRIF) (Akira et al., 2006; Yamamoto et al., 2002).

Some studies have highlighted that single commensal species can shape the Thelper and T-regulatory (T-reg) subsets in the gut lamina (Nutsch et al., 2016). For example, Th17 act a double role: in homeostatic conditions they have a defensive role against pathogen bacteria, but a colonization with segmented filamentous bacteria (SFB) in mice induces an accumulation of Th17 and also an increase in Th1 cells, interestingly via adhesion mechanisms enterocytes-SFB and not PRRs mediated (Ivanov et al., 2009). This induction was related with autoimmune disorders (e.g. uveitis and multiple sclerosis) and GF mice colonized with only SFB can promote experimental autoimmune encephalomyelitis correlated with not-colonized controls (Lee et al., 2011). On the other hand, the gut microbiota is necessary for the function and development of T-reg cells and/or for inducing of interleukin (IL) 10 expression. Indeed, in a mouse model, the bacterium Bacteroides fragilis induces T-reg cells (exclusively in the FOXp3+ population) by the capsular expression of polysaccharide A (Geuking et al., 2011), whereas some Clostridium cluster exert the same effect but with uncertain mechanisms (dependent on My-D88 or independent of PPRs in general)(Round et al., 2011). Also mast cells, innate immune cells involved in the immunological homeostasis and in parasitic infections, have demonstrated altered functionality in GF mice and impaired gut homing (Schwarzer et al., 2019) as well as a major role in neuro-immune interactions as extensively reviewed in 
(Forsythe, 2019). Stimulating the receptors of mast cells-derived mediators (e.g. histamine, bradykinin, 5-HT) expressed on vagal and spinal afferents in the gut, mast cells can modulate firing nerves threshold and increase intestinal motility and mucosal secretions (Wouters et al., 2016).

In a steady-state condition, the gut microbiota create an ultra-low activation of the immune system, with stimulation of several types of T cells and macrophages to secrete pro-inflammatory cytokines (e.g. IL-1 $\beta$ and TNF- $\alpha$ ) (Belkaid and Hand, 2014). This intestinal chronic state of immune activation can eventually involve the entire body without consequences on health (Blander et al., 2017). An upregulation of the inflammatory state, due to various factors (e.g. microbiota alterations and increased barrier permeability), can lead to an activation of a peripheral immune response with increased cytokine/chemokine signalling through neuronal or humoral pathways that could trigger a mirrored inflammatory response in the CNS; this might have transient or long-term effects on seizure susceptibility by lowering the seizure threshold (Riazi et al., 2004, 2008, 2010). Both blood-brainbarrier (BBB)-dependent and independent pathways have been proposed (Quan, 2008); these include microglial activation, the expression of TLRs and IL-receptors in the brain, vagal afferent networks and disruption of the BBB (Oby and Janigro, 2006a; Block et al., 2007; D’Mello et al., 2009; Murta et al., 2015; Abbott et al., 2010).

\subsection{The blood brain barrier}

The BBB begins to develop during the first phases of intrauterine life and, further than barrier functions, regulates efflux and influx of the molecules and ions and protect the brain from toxins and pathogens (Obermeier et al., 2013). It is formed by capillary endothelial cells, astrocytes, pericytes and tight junctions (mainly transmembrane proteins as claudins, occludin and tricellulin connected with cytoskeleton). Despite several studies provide evidence on CNS related mechanisms underlying the development of the BBB, the influence of peripheral inputs is poorly understood.

The gut microbiota could have a role in BBB integrity; CNS changes have been observed in GF mice and in mice treated with antibiotics or probiotics. Indeed, a recent study demonstrated that GF mice 
were associated with increased BBB permeability and lower expression of occludin, and claudin-5 (another tight junction protein involved in BBB permeability) in different brain regions (Braniste et al., 2014). On the other hand, colonization of adult and prenatal GF mice with faecal gut-microbiota, increased occludin and claudin-5 expression and decreased BBB permeability. Furthermore, fetal mice with GF-mothers showed a more permeable BBB compared with control fetal mice suggesting a MGB communication since gestation.

3.3 Nowadays, CNS inflammation, with or without BBB integrity, has been identified as a main factor in seizure physiopathology inducing a vicious cycle: neuro-inflammation primes seizures causing cell death, and epileptic seizures themselves induce an inflammatory response by activation of immune cells, microglia and production of pro-inflammatory cytokines, which sequentially activate more inflammation contributing to the development of epilepsy (Devinsky et al., 2013; Marchi et al., 2007; Vezzani et al., 2008). Dysregulation in thegut microbiota composition and BBB permeability might be the primum movens of this vicious cycle (FIG. 2) but, despite various evidence, the definite mechanisms that link gut microbiota, peripheral inflammation and the neuro-immune response need to be clarified.Neuromodulators

Neurotransmitters (e.g. GABA, 5-HT and dopamine) and neuropeptides (e.g. substance P, calcitonin gene-related peptide, neuropeptide Y [NPY], vasoactive intestinal polypeptide [VIP]), are crucial in MGB axis connection and contribute to the mutual microbiota-host interaction (Holzer, 2016). On the other hand, the same neurotransmitters and neuropeptides along with $\mathrm{Na}^{+}, \mathrm{Ca}^{2+}$ and $\mathrm{K}^{+}$channels are clearly involved in epilepsy among others (Avoli et al., 2005; Werner and Coveñas, 2015).

The gut-microbiota produces neurotransmitters and neuropeptides identical to those produced by mammalian cells (Jandhyala et al., 2015). Different species produce different neurotransmitters: Enterococcus spp., Streptococcus spp., and Escherichia spp. produce 5-HT; Lactobacillus spp. and Bifidobacterium spp. produce GABA, while Escherichia spp. and Bacillus spp. produce noradrenaline and dopamine (Roshchina, 2010). Moreover, the microbiota in the intestine is able to 
produce metabolites with benzodiazepine-like structures (Hu et al., 2007; Yurdaydin et al., 1995). However, it is highly improbable that neurotransmitters produced in the gut can influence directly the brain, with the exception of GABA, considering that its transporters are localized on the BBB and could allow gut-derived GABA to reach the CNS (Takanaga et al., 2001). Despite the fact that they can cross the intestines' mucosal layers, the BBB is unpassable for them. Indeed, all of these neurotransmitters may influence brain function indirectly, by acting via the enteric nervous system (ENS), vagus nerve (Bravo et al., 2011) and by modulating peripheral receptor expression (Mittal et al., 2017). Moreover, gut microbiota alters the levels of indispensable bricks needed to produce neurotransmitters; the precursors of dopamine, noradrenaline and serotonin, TRP and tyrosine, are lower in the brain of GF mice compared with re-colonized mice, whereas in the hippocampus, 5-HT and its metabolite hydroxyl-indoleacetic acid are higher. GF mice showed also an increased concentration of TRP, 5-HT and tyrosine in the blood plasma (Heijtz et al., 2011).

Furthermore, $\alpha$-lactalbumin, a protein rich in TRP, exerts significant protective activity against seizures mediated by an increased availability of TRP in the brain of mice, with a consequent increase in 5-HT-mediated transmission (Citraro et al., 2011). The role and mechanisms of gut microbiotaproduced neuromodulators overall, and specifically in epilepsy needs to be clarified. Recently, using shotgun metagenomics analysis it has been shown that there are at least 46 different gut-brain axis modules with neuroactive potential and that the levels of these are altered in major depression (Cryan and Dinan, 2019; Valles-Colomer et al., 2019). Future studies should investigate if any of these modules are also affected in epilepsy.

\subsection{Short-chain fatty acids (SCFAs)}

In the gut microbiota, some bacteria phyla (mainly Bacteroides and Firmicutes) can ferment insoluble dietary fibres resulting in the production of SCFAs, including acetate, propionate, and butyrate (den Besten et al., 2013). SCFAs exert multiple beneficial effects on mammalian metabolism, like being an energy source for colonic epithelial cells (Ahmad et al., 2000) and can induce the expansion of 
colonic T-reg cells (Smith et al., 2013). Lack of dietary fibre intake has been associated with a low concentration of SCFAs and the development of inflammatory bowel disease (Maslowski and Mackay, 2011; Pituch-Zdanowska et al., 2015). Preclinical studies demonstrated that SCFAs have a role in the modulation of visceral pain (Russo et al., 2016) and butyrate orally administered, can reduce neutrophil recruitment and inflammation in dextran sulphate sodium-induced colitis (Simeoli et al., 2017). Recently, it was shown that SCFAs also have a critical role in brain development and are essential for several neurophysiological functions such as microglia maturation, autonomic nervous system stimulation by enteric neurones and permeability regulation of the BBB (Braniste et al., 2014; Erny et al., 2015b) as well as playing a role in the stress response (van de Wouw et al., 2018). Their influence on the brain can be indirectly mediated by metabolism and immunity or directly mediated through G-protein-coupled receptors [SCFA receptors, FFAR3 and HCAR2 (Bolognini et al., 2016; Fu et al., 2015)] or act as epigenetic modulators by histone deacetylases (Bolognini et al., 2019; Citraro et al., 2018; Stilling et al., 2016).

Histone modifications are crucial for regulating neurobiological processes (e.g. neural network function, synaptic plasticity and synaptogenesis) and alterations in these processes are involved in the pathogenesis of epilepsy and epileptogenesis (Citraro et al., 2019; Henshall and Kobow, 2015; Qureshi and Mehler, 2010). Indeed, recent evidence has shown that abnormal post-translational histone and altered gene expression are hallmark features of animal models of status epilepticus and temporal lobe epilepsy (Henshall and Kobow, 2015). Despite the therapeutic effect of SCFAs being demonstrated also in animal models of Parkinson's, Alzheimer's and Huntington's diseases (Ho et al., 2018; Naia et al., 2017; Unger et al., 2016), no human studies have been performed so far.

\subsection{The hypothalamic-pituitary-adrenal axis}

The hypothalamic-pituitary-adrenal axis is the most important neuroendocrine component of the stress response, with secretion of corticotrophin-releasing factor (CRF), adrenocorticotropic hormone $(\mathrm{ACTH})$ and subsequent release of glucocorticoids (e.g. cortisol, corticosterone, deoxy-corticosterone 
and corticotrophin) and catecholamine downstream pathways (Mayer, 2000). Alterations in the stress responses and in HPA-related hormones have been identified in the pathophysiology of several neurological and psychiatric diseases, principally in anxiety and depression but also in epilepsy (Ciriaco et al., 2013; Collins and Bercik, 2009; Maguire and Salpekar, 2013; O’Mahony et al., 2009). Preclinical studies indicate a pro-epileptic role for this system; for examples, exogenous cortisol administration induces epileptiform activity in response to sub-threshold stimulation (Pritchard et al., 1985), and corticosterone increases absence seizures (epileptiform discharges) in WAG/Rij rats (Schridde and Van Luijtelaar, 2004), and seizure susceptibility to kainate (Roberts and Keith, 1994), in amygdala (Taher et al., 2005) and hippocampal kindling (Karst, 1999). Also, clinical evidence suggests a link between stress and epilepsy; several patients self-report that stress triggers or exacerbates their seizures (Maguire and Salpekar, 2013). Moreover, basal levels of stress hormones (as well as plasma cortisol levels), are increased in patients with epilepsy compared with controls and obviously increase after seizures, indicating a bidirectional link.

Finally, high cortisol levels are also related with major depressive disorder (Schatzberg et al., 2014), and the HPA axis may also contribute to the comorbidity of depression in epilepsy (Tao and Wang, 2016). However, despite this evidence, studies examining specifically the causal relationship between HPA axis dysfunction and epilepsy are limited. It was demonstrated that this neuroendocrine connection is a key pathway in the MGB axis and can both modulate and be modulated by the gut microbiota as shown, for the first time by (Sudo et al., 2004a), in a study with adult GF mice and later confirmed by other studies (Bailey et al., 2011; Bangsgaard Bendtsen et al., 2012). An exaggerated release of ACTH and corticosterone was observed after exposure to mild stress compared to control mice (with normal gut microbiota and no-specific pathogens), and this was partially and fully reversed restoring the microbiota or after mono-administration of Bifidobacterium infantis, respectively (Sudo et al., 2004a). Moreover, in the hippocampus and cortex of male GF mice, the authors observed a decrease in brain-derived neurotrophic factor (BDNF), a neurotrophin involved in neuronal plasticity. BDNF, as reviewed in (Kowiański et al., 2018), has important effects on neuronal activity, principally 
in the hippocampus, with modulation of excitatory and inhibitory synaptic transmission in epileptogenesis and epilepsy.

Although the HPA bidirectional link with gut microbiota is well recognized and largely studied in psychiatric diseases, as recently reviewed in (Cheung et al., 2019), studies to determine a direct correlation between epilepsy, the HPA axis and gut microbiota are lacking. A better understating of this pathway could be useful for the development of novel target therapies and non-pharmacological interventions to prevent seizures and treat psychiatric comorbidities in epilepsy.

\subsection{The endocannabinoid system}

The endocannabinoid system (ECS) has emerged as an important neuro-modulatory pathway over the last 25 years. The ECS includes cannabinoid receptors (with the most relevant being CB1Rs and CB2Rs), endogenous cannabinoids (endocannabinoids), and the enzymes responsible for their synthesis and degradation (Pertwee, 2006). It shows important roles in CNS development, synaptic plasticity, and in response to endogenous and environmental insults. CB1Rs are highly abundant in the CNS, while CB2Rs are predominantly expressed in the gut, neurones, epithelial and immune cells (Acharya et al., 2017; Cabral et al., 2015). Furthermore, recent studies demonstrated that CB1 receptors don't reach the cell surface but are highly expressed and functional in lysosomal and endosomal compartments (Brailoiu et al., 2011).

Some studies have indicated that diet-induced obesity and associated-inflammatory disorders may be directly correlated to a dysregulation of the ECS; accordingly, evidence supports the presence of a peripheral ECS that is upregulated in human obesity with increased ECS levels in plasma and adipose tissue and a correlated alteration of CB1Rs (Engeli et al., 2005; Izzo et al., 2009). Emerging evidence denotes that the ECS is an important component of the MGB axis and that its role in obesity and 
correlated inflammatory disorders can directly involve the gut microbiome. Indeed, a study showed an interaction between the gut microbiota and ECS using GF mice; after administration of antibiotics and probiotics, they demonstrated that alterations in the ECS are involved in the dysregulation of LPS levels, gut integrity disruption, development of a chronic inflammatory state and alterations in the gut microbiota composition (Muccioli et al., 2010). In rodent models, Akkermasia muciniphila and Lactobacillus acidophilus can induce the expression of cannabinoid receptors and increase levels of endocannabinoids in the gut (Everard et al., 2013; Rousseaux et al., 2007). Moreover, a study has shown that LPS leads to dysregulation of the ECS in macrophages; LPS causes robust production of endogenous ligands for cannabinoid receptors, specifically anandamide (arachidonylethanolamide, AEA) in adipose tissue and macrophages, which contributes to exacerbation of chronic inflammation in visceral fat, hyperglycaemia and insulin resistance with systemic consequences (MehrpouyaBahrami et al., 2017).

In epilepsy, several experiments using animal models have demonstrated a role for the ECS and above all CB1Rs, in controlling neuronal excitability and potential antiepileptic effects, and various direct synthetic cannabinoids have been tested in animal and in in vitro models as reviewed in De Caro et al. (2017). Furthermore, some studies suggest that the LPS-induced peripheral inflammation could cause an increase in seizure susceptibility via BBB-dependent or independent pathways as above mentioned (e.g. COX-2-dependent neuroinflammation in the hippocampus and upregulated expression of the chemokine CCL2) (Ho et al., 2015; Cerri et al., 2016). Despite the theoretical correlation between the ECS, LPS and epilepsy, no studies have yet been performed to demonstrate direct mechanisms.

\subsection{The excitation and inhibition (E/I) balance}

The excitation and inhibition balance refers to the relative contributions of excitatory and inhibitory synaptic inputs that helps to maintain neuronal homeostasis. The E/I balance is a dynamic process in 
the brain; a continuous interchange between glutamate and glutamine, and glutamate and GABA, involving several enzymes (e.g. glutamic acid decarboxylase and glutamine synthetase) (Sohal and Rubenstein, 2019). Metabolic, immune, and environmental stimuli might compromise the E/I balance. Dysregulation of this balance, due to enhancement of glutamatergic neurotransmission and/or a suppression of GABAergic neurotransmission, was entailed in the pathophysiology of epilepsy (DiNuzzo et al., 2014), schizophrenia and autism spectrum disorders (Foss-Feig et al., 2017; Horder et al., 2018; Lee et al., 2017), depressive disorder (Luscher and Fuchs, 2015) and information processing and social dysfunction (Yizhar et al., 2014).

As above mentioned, some studies have demonstrated that gut microbiota can influence in several ways the glutamine-glutamate-GABA cycle, producing neurotransmitters, amino-acids and modulating GABA and NMDA receptors expression in specific brain regions (e.g. hippocampus, amygdala, locus coeruleus). Indeed, it was shown a modulation in mRNA expression of GABAB1b and $\mathrm{GABA}_{\mathrm{A} \alpha 2}$ in mice treated with Lactobacillus rhamnosus compared to control mice. In particular, $\mathrm{GABA}_{\mathrm{B} 1 \mathrm{~b}}$ was increased in cingulate and pre-limbic areas and reduced in hippocampus, locus coeruleus and amygdala, whereas $\mathrm{GABA}_{\mathrm{A} \alpha 2}$ was reduced in cortex and increased in the hippocampus (Bravo et al., 2011). Subsequently another study, using the same bacteria strain for 4 weeks, analyzed GABA, N-acetyl aspartyl glutamic acid and glutamate at the end of treatment and again 4 weeks after cessation. All the neurometabolates were found increased in the brain at the end of probiotic administration, and glutamate was still elevated 4 weeks after the cessation of treatment, suggesting that changes in gut microbiome could affect the brain through defined metabolic pathways (Janik et al., 2016).

The study of Liang et al. demonstrated that gut microbiota disturbance in childhood induced persistent changes in emotional behaviour and the expression of GABA-A receptor $\alpha 5$ and $\delta$ subunits in the hippocampus of the adult rat. Probiotic administration (Lactobacillus rhamnosus and Bifidobacterium longum) could increase the expression of these subunits and led to a significant symptoms improvement (Liang et al., 2017). Furthermore, a diet containing prebiotics (i.e. galacto- 
oligosaccharide, polydextrose), lactoferrin, and milk fat globule membrane significantly increase mRNA expression for BDNF and the Glu-N1 subunit of the NMDA receptor in the prefrontal cortex and decreased anxiety-related behavior in juvenile rats (Mika et al., 2018). Also the only ingestion of the prebiotic galacto-oligosaccharide has been associated with an increase in cortical NMDA receptor function and a pro-cognitive effect in rats (Gronier et al., 2018).

As previously discussed, Sudo et al. demonstrated, in addiction to altered BNDF levels, a decreased expression of Glu-N2A (subunit of NMDA receptor) that could result in vulnerability to damage and reduced synaptic potentiation in GF mice (Sudo et al., 2004b). Also performing a faecal microbiota transplant (FMT) in GF mice by patients with schizophrenia can impact the E/I balance; lower glutamate and higher glutamine and GABA levels in the hippocampus, as well as a behaviours characteristic of schizophrenia, have been demonstrated after FMT in these mice (Zheng et al., 2019). In epilepsy, disruption of E/I balance, with a perturbed glutamate-glutamine cycle, seems to be the most obvious mechanism leading to hyper-excitability and resulting hypersynchronous neuronal activity at the beginning of seizures as reviewed in (DiNuzzo et al., 2014; Eid et al., 2012; Fritschy, 2008), despite the concept of E/I balance is simplified and perhaps misrepresentative of epileptogenesis. Indeed, several gaps of knowledge as the peripheral metabolism in the cycle homeostasis, the regulation of enzymes and receptors and the role of the cycle in cell signaling need to be filled. Future studies are mandatory to understand the role of the gut microbiota and its influence on E/I balance in epilepsy and to discover innovative therapeutic targets.

\section{The gut-microbiota in epilepsy}

Overall, current evidence has decisively established that the gut microbiome influences brain function and vice-versa, providing a rationale for studying directly, the MGB axis and its complex pathways in epilepsy. The pre- and clinical studies have followed two main approaches; the first is a comparison between different rodent models (e.g. GF and colonized) or healthy-patient groups (e.g. drug-resistant epilepsy patients vs controls), looking for differences in microbiota compositions. The second is 
interventional, through microbiota manipulation with probiotics, prebiotics, antibiotics or diet, evaluating outcomes in the CNS. Only one case report correlating epilepsy and gut microbiota is present in the literature (He et al., 2017). To date, the small number of preclinical and clinical studies, considering several limitations and lack of standardisation, seems to corroborate this direct link between the gut microbiota and epilepsy.

\subsection{Insights from animal models}

Animal models are critical for understanding the mechanisms of how the microbiome affects the brain. Researchers have recently identified microbial and gut alterations linked with almost all major brain disorders (Sherwin et al., 2017) opening up the possibility that epilepsy too could potentially be related to changes in the gut-microbiota.

Indeed, at a mechanistic level in animal models, it has been clearly demonstrated that the gut microbiota is contributing to the development of behavioural symptoms and neuroinflammation in Parkinson's disease (Sampson et al., 2016), stroke (Benakis et al., 2016) and experimental autoimmune encephalomyelitis (EAE) (Berer et al., 2017; van den Hoogen et al., 2017), stressinduced changes in intestinal inflammation (Zhang et al., 2017), brain function and behaviour (Burokas et al., 2017), and E/I imbalance in autism (Liu et al., 2019). Thus, neurological conditions accompanied by an altered microbiota composition may be the result of an earlier and non-identified event on the MGB axis. For example, it is known that maternal immune activation (MIA) contributes to the development of behavioural alterations in rodent offspring and altered microbiota composition (Hsiao et al., 2013).

Finally, a recent study in rats reported the effect of a probiotic mixture (Lactobacillus rhamnosus, Lactobacillus reuteri, and Bifidobacterium infantis) administration in a pentylenetetrazole (PTZ)induced model of kindling (Bagheri et al., 2019), substantively reduces seizure severity and epileptic activity compared to controls. Moreover, performance at water maze test has been improved by probiotics in all groups and elevated levels of GABA have been found in brain, but only in the group 
with probiotics administration during kindling. Lastly, the intervention reduced nitric oxide and malondealdehyde concentration and increased total antioxidant capacity in the brain.

\subsection{Ketogenic diet and microbiome}

The ketogenic diet is a high fat, low-carbohydrate and medium-high protein diet, inducing ketone bodies production and mimicking starvation. Calories in the traditional KD are subdivided in $90 \%$ from fat and 10\% from carbohydrate and proteins (Lutas and Yellen, 2013). The KD is principally used in the paediatric population with drugs-resistant epilepsy, effectives for both partial and generalized seizures, including the glucose transporter protein 1 deficiency syndrome (GLUT1-DS) and pyruvate dehydrogenase deficiency syndrome (PDHD) (Yifan Zhang et al., 2018). Lately, the $\mathrm{KD}$ has been tested for other conditions ranging from autism spectrum disorders to chronic pain, multiple sclerosis and cancer (Boison, 2017).

The recent study by Olson and colleagues, used two mouse models (the 6-Hz induced seizure model and the $\mathrm{Kcna1}^{-}$genetic model of temporal lobe epilepsy), to investigate whether the antiepileptic effect of the ketogenic diet is mediated through the gut microbiota (Olson et al., 2018). Indeed, after an antibiotic treatment to reduce gut microbial population or in GF mice undergoing a 6-Hz stimulation protocol, KD failed to prevent seizures, whereas a FMT from KD-treated mice into control diet mice was sufficient for seizure protection. KD modifies the gut-microbiota, decreasing the $\alpha$-diversity with an increase of relative abundance in Akkermansia muciniphila, Parabacteroides merdae, Sutterella and Erysipelotrichaceae. Transferring the microbiota by FMT from KD mice, increases seizure threshold in mice fed by standard diet and also co-administration of Akkermansia muciniphila together with Parabacteroides merdae, but not alone, restores seizure protection, suggesting that both together raise seizure threshold in the absence of other gut microbes. In a metabolomics analysis after KD and microbial treatment, the authors found a reduced $\gamma$ glutamyltranspeptidase (GGT) activity in faeces, a decrease in $\gamma$-glutamylated (GG) ketogenic amino acids (e.g., leucine, lysine, tryptophan, and tyrosine) in serum and in the gut, and an increased level 
of GABA relative to glutamate content in the hippocampus. Accordingly, the protection against seizures seems to be due to a decreased availability of amino acids blocking GGT activity and an increasing in the GABA tone (Olson et al., 2018). Two studies in BTBR and C57BL/6j mice reported similar changes in gut microbiota due to $\mathrm{KD}$, but different taxonomic shifts were observed (Klein et al., 2016; Newell et al., 2016) and the KD or dietary intervention are currently being considered for the treatment of autism spectrum disorders (Doenyas, 2018; Lee et al., 2018).

In conclusion, relevant aspect would be to study the gut microbiota as a diagnostic biomarker; not only stool samples could be used but also peripheral blood could be studied to identify specific transcripts related to an altered gut-microbiome (Walker et al., 2016).

\subsection{Clinical evidence}

Few comparative and interventional clinical studies have been so far reported on the link between gut microbiota and epilepsy, mostly focused on the effect of the KD, in drug-resistant patients (Table 1 and 2). To explore whether gut microbiota alterations are involved in the mechanism of drug-resistant epilepsy, Peng et al. (2018) analysed the gut microbiome composition in drugs sensitive and resistant patients compared to a healthy group. Alpha-diversity is increased and gut microbiota composition is enriched in rare microbes in the drug resistant group (i.e. Verrucomicrobia), whereas bacteria population and $\alpha$-diversity was similar between control and drugs-sensitive patients. Specifically, bacteria enriched in the drug resistant group included species associated with neurotransmitter production and metabolic pathways of the ATP-binding cassette transporters (ABC) (Peng et al., 2018). For example, Ruminococcus was reported to be associated with a lower level of $\mathrm{N}$-acetyl aspartic acid (NAA), a marker of neuronal health reduced in patients with epilepsy, a decreased level of 5-HT and with impairment in the synthesis and metabolism of the ABC transporters (Bedarf et al., 2017). These are the first data in humans that prove a clear difference in gut microbiota composition between drug-resistant and drug-sensitive patients with epilepsy; it could be supposed, if confirmed 
by other studies, that a role of microbiota and its mediators exists in drug-resistant mechanisms and in any case, these differences may be considered as a biomarker.

Furthermore, in spite of studies reporting an increased risk of seizures while taking penicillins, fourthgeneration cephalosporins, imipenem, and ciprofloxacin (particularly in patients with renal dysfunction, brain lesions and epilepsy) (Sutter et al., 2015), evidence for the association between seizure incidence and antibiotic treatment remains elusive. In a retrospective study including only six patients with drug-resistant epilepsy, Braakman and van Ingen (2018), speculated on the possible beneficial impact of antibiotics on seizure frequency mediated by changes in the gut microbiome, by observing that five patients became temporarily seizure-free during antibiotic treatment (in particular, using one among azithromycin, clindamycin, amoxicillin/clavulanic acid and piperacillin/tazobactam). This positive beneficial effect on seizure frequency however, disappeared within 2 weeks after antibiotic cessation, and whether this effect was gut-mediated remains unknown, as no microbiota analysis was performed (Braakman and van Ingen, 2018).

Regarding the use of pre- or pro-biotics in patients with epilepsy there is only one reported study (Gómez-Eguílaz et al., 2018) The authors evaluated the effects of 4-months probiotic supplementations (a mixture containing 8 different bacterial subspecies of Lactobacillus, Bacteroides and Streptococcus species) in 45 patients with drug-resistant epilepsy. The study revealed that probiotics reduced seizure number $(\geq 50 \%$ in $28.9 \%$ of the patients [Intention-To-Treat analysis]) and improved the Quality of Life score (mean \pm SD: $19.23 \pm 6.04$ vs $26.45 \pm 9.7 ; \mathrm{P}=0.013$ ) in patients with drug-resistant epilepsy. However, the authors were unable to demonstrate the way by this improvement occurred, and a microbiota analysis before and after treatment was not performed.

Although it is well established that diet can deeply change microbiota composition and metabolism (Zmora et al., 2018), the mechanisms underlying KD effects on seizure incidence are not completely explained (Augustin et al., 2018). Recently, several studies in diverse animal models (e.g. c57Bl/6, BTBR) showed that the KD compared to a control diet, acts significantly on gut microbiota with different findings (Figure 3), and it was reported above that KD anti-seizures effects are clearly 
mediated by the intestinal microbiota (Olson et al., 2018). Translated in humans, Xie et al. (2017) investigated the gut microbiota differences between 14 children with epilepsy and 30 healthy infants and how KD modifies microbial species. Higher gut microbiota diversity was demonstrated in healthy infants compared to drug-resistant patients and that KD treatment can correct an imbalanced gut microbiome in epileptic infants, making it more similar to healthy subjects. After KD treatment, Bacteroidetes, but not Firmicutes and Actinobacteria, increased significantly whereas Proteobacteria decreased. Bacteroidetes, could have a role in seizure regulation; regulating IL-6 and IL-17 secretions in dendritic cells, a process involved in seizure severity, and producing SCFAs. However, epileptic patients differed substantially from healthy infants, but an analysis at function and species level is necessary to understand the underlying mechanisms (Xie et al., 2017).

Another study evaluated the composition of the gut microbiota before and after three months with KD in six patients with GLUT1-DS (Tagliabue et al., 2017a). Contrasting with Xie et al. data, no statistically significant differences in Firmicutes and Bacteroidetes were reported. Interestingly, the main finding was a significant increase in Desulfovibrio spp. $(\mathrm{P}<0.025)$, a sulphate-reducing and pro-inflammatory bacterial group. However, results seemed to show a general gut microbial depletion after KD treatment. The effects of the KD on gut microbiota was also confirmed in a study involving 20 patients with epilepsy, showing that after 6-months of KD in 10 responder patients (achieving $>50 \%$ reduction in seizure frequency), there was a decreased alpha diversity and a significant increase in the abundance ratio of Bacteroidetes and a decreased abundance of Firmicutes and Actinobacteria In the efficacy subgroup analysis, at family level the non-responsive patients had a differentially modified gut microbiota compared to responsive patients. (Yunjian Zhang et al., 2018).

In animal models, a loss of endothelial barrier antigen in brain micro-vessels was demonstrated to be due to high levels of Clostridium and Clostridia neurotoxins that can affect the CNS through the axon transport pathway (Finnie et al., 2014). Nevertheless, the relationship between these bacteria and epilepsy is still unknown. In these three studies, results of richness and alpha-diversity reduction after $\mathrm{KD}$ are similar although Bacteroides-Firmicutes ratio diverges as does the modulation of several 
specific bacterial species. Recently, Lindefeldt and colleagues partially confirmed these findings. They enrolled 20 patients with therapy-resistant epilepsy starting the KD and 11 healthy parents as controls. Faecal samples were collected before and after 3 months starting the KD. In this cohort, 5 patients responded with a $>50 \%$ decrease seizure frequency and in 10 children, improved cognition and motor functions were observed. Alpha-diversity, lower in patients than in controls before treatment, was not significantly decreased after the KD. After three months of KD treatment, Actinobacteria, decrease in agreement with Zhang et al., as well as Eubacterium rectale and genus Dialister (not found modified in previous studies), and Proteobacteria and genus Escherichia increase. A depletion of Bifidobacterium and E. coli could cause a decreased production of antiinflammatory SCFAs (butyrate and acetate) with direct consequences on human health; according to Tagliabue et al., the authors were concerned about harmful effects of the KD on gut health (Lindefeldt et al., 2019a).

a treatment.

Finally, no trials have been performed yet with FMT in epilepsy (except a trial [Faecal Microbiota Transplantation for Epilepsy; NCT02889627] with recruitment in progress), and C.Difficileintractable colitis remains the only approved indication for FMT. However, a first case report about FMT and epilepsy was reported in the literature (He et al., 2017). A faecal trasplant was performed in a 20-year-old patient with Crohn's disease and a 17-year history of epilepsy (120 seizures per year) that led to a 20 months seizure-free period without concomitant antiepileptic drug therapy. Unfortunately, in this case report, there was no gut microbiome analysis, no confirmed focal pathology and no potential pathogen identification. Furthermore, the article did not have enough clinical details to really define or understand the case, raising some doubts about the outcome, even though this case report appeared particularly impressive.

Therefore, there is a paucity of published data on the relationship between gut microbiota and epilepsy in humans, and there is no actual consensus on the results already obtained. The use of different methods for microbiota analysis, dissimilar levels of taxonomic insights, the heterogeneity of the 
epilepsy cohorts in which different aetiologies were included and a lack of standardisation make it very arduous to compare data. Bearing in mind that people living in different countries or using different diets have varied gut microbiota compositions without any interference with health (Albenberg and $\mathrm{Wu}, 2014$ ), set what is a normal gut microbiota composition is a challenge for future controls/patients comparative studies. There is therefore, a need for both preclinical and welldesigned, randomized human studies to clarify the role of the gut-microbiota-epilepsy network and whether there will be space for novel epilepsy treatments targeted at the microbiome composition.

\section{Other aspects}

Further than epilepsy, seizures can also occur occasionally in non-epileptic disorders including stroke, and hepatic encephalopathy (HE) and the gut microbiota is emerging as a co-factor and a potential strategy to treat these disorders.

Cerebral cavernous malformations (CCMs) are common vascular malformations in CNS and a cause of stroke and seizure (Fischer et al., 2013). A recent study has shown an unexpected role of the microbiome, specifically Bacteroidales $S 24-7$, acts as the primary source of TLR4 ligand, necessary to $\mathrm{CCM}$ formation in mice and variations to the microbiome can ameliorate CCM disease (Tang et al., 2017). However, as highlighted by Starke and colleagues (Starke et al., 2017), is necessary to understand if the human microbiome, don't holding Bacteroidales S24-7, is also responsible for CCMs formation or progression.

Gut microbiota seems to play also a critical role in the progression of cirrhosis and its complications as hepatic encephalopathy. Treatments for HE are overall gut-centric as non-absorbable antibiotics (neomycin and rifaximin), lactulose, prebiotics and several combination of probiotics (Suraweera et al., 2016), underling the role of the microbiota in HE pathogenesis.

Lactulose treatment was able to reduce the bacterial-DNA translocation rate, with decrease in ammonia levels, inflammatory mediators and an improvement in cognitive scores (Moratalla et al., 2017). Moreover, growing evidence have shown that alteration in gut microbiota composition and 
correlated metabolites, could drive HE development through local and systemic inflammation (Bajaj, 2014). It was shown in HE patients a different gut composition (e.g. lower Roseburia and higher Enterococcus) correlated to controls (Bajaj et al., 2012) and specific microorganisms have been also correlated with hyperammonemia-associated astrocytic change (Enterobacteriaceae) and with ammonia-independent neuronal changes (Porphyromonadaceae), highlighting the link between specific bacteria taxa and brain consequences of cirrhosis (Ahluwalia et al., 2016). Thus, gut microbiota could have a role in seizures, and overall on neurologic symptoms, related with HE or stroke but, nowadays, only few studies have been performed and no one focused specifically on seizures. Further translational studies are necessary to deeper explore the role of gut microbiota in the physiopathology of these diseases and to develop focused gut-based therapies involving specific bacteria strain.

\section{Conclusion and perspectives}

In the last years, the gut microbiota as a potential factor in epilepsy and epileptogenesis has gained importance in the scientific community as demonstrated by the rising number of studies and two recently published reviews (Dahlin and Prast-Nielsen, 2019; Lum et al., 2019) specifically focused on the topic; however, only few preclinical and clinical studies (often underpowered and gathered only on bacteria taxa) have been performed so far.

The pathophysiological mechanisms investigated to date, point out the interaction between gut microbiota and local/systemic diseases, but the data available don't allow us to determine whether correlation (e.g. changes in microbiota populations) implies causation (e.g. seizures onset/maintenance). Indeed, which is the primum movens entailed in this potential dualism between the gut-microbiota and the epilepsy through the MGB axis is still unknown. Future researches should be aimed at understanding whether the epilepsy itself shapes first the microbiota, or whether differences in microbiota-composition (from birth or modified during lifetime) can be the cause of seizures onset and maintenance. However, regardless to the first mechanism involved, a vicious cycle 
between seizures and gut-microbiota shifts could be supposed. Also the role of specific neural, metabolic, endocrine and immune pathways in microbiota-gut-brain communication and its relative contributions to epilepsy have to be clarified and deep investigated.

Overall, it is challenging to explore microbiota modifications and their influences on the host, especially regarding CNS diseases; indeed, epilepsy is a highly heterogeneous disorder with significant differences in pathogenesis, clinical manifestations and treatments (e.g. differences among children and adults or genetic and idiopathic aetiology), making microbiome studies more intricate with the involvement of several variables.

Acute and chronic treatments can shape the gut microbiota and, vice versa, the microbiota itself can influence the actions of a range of xenobiotics (Clarke et al., 2019). To date, there are no studies evaluating the direct impact of antiepileptic drugs on intestinal microbial populations performed in humans, whereas in vitro evidence recently demonstrated that valproate markedly affects microbiota composition in an animal model (Cussotto et al., 2018) and zonisamide is metabolized to 2sulfamoylacetylphenol by gut microbiota (Kitamura et al., 1997). Moreover, Maier et al. have shown the extensive impact of non-antibiotic drugs on gut bacteria proliferation (Maier et al., 2018b), although of the 16 drugs included in the subgroup N03A of controlled ATC (Anatomical Therapeutic Chemical), classification that comprise antiepileptic drugs, none have shown antimicrobial effects, even though lamotrigine have demonstrated to inhibit E. coli ribosomal biogenesis (Dahlin and PrastNielsen, 2019; Stokes et al., 2014). Any speculation regarding the role of gut microbiota on antiepileptic drugs metabolism and thus their clinical efficacy, or the effective impact of long term treatment on microbial population is still premature.

New therapeutic options are necessary for patients with epilepsy, above all for the $30 \%$ of them with a drug-resistant disease, and microbiome-specific therapeutic strategy could be a valid option. However, several future studies are mandatory to establish whether microbe-based treatments can be effectively and securely used for clinical improvement of seizure frequencies, severity and epilepsyrelated disorders. 
Elucidating the connection between the MGB axis and epilepsy could lead also to the discovery of useful biomarkers and to advance the knowledge on the complex mechanisms underlying epileptogenesis and epilepsy themselves.

\section{Conflict of Interest}

J.F.C. received research funding from Dupont, Nutrition, Cremo SA, Alkermes Inc., 4D Pharma PLC, Mead Johnson Nutrition and Nutricia Danone.

E.R. has received speaker fees and participated at advisory boards for Eisai and has received research fundings by GW Pharmaceuticals, Pfizer, Italian Ministry of Health $(\mathrm{MoH})$ and the Italian Medicine Agency (AIFA). 


\section{References}

Abbott, N.J., Patabendige, A.A.K., Dolman, D.E.M., Yusof, S.R., Begley, D.J., 2010. Structure and function of the blood-brain barrier. Neurobiol. Dis. 37, 13-25.

https://doi.org/10.1016/j.nbd.2009.07.030

Acharya, N., Penukonda, S., Shcheglova, T., Hagymasi, A.T., Basu, S., Srivastava, P.K., 2017. Endocannabinoid system acts as a regulator of immune homeostasis in the gut. Proc. Natl. Acad. Sci. 114, 5005-5010. https://doi.org/10.1073/pnas.1612177114

Ahluwalia, V., Betrapally, N.S., Hylemon, P.B., White, M.B., Gillevet, P.M., Unser, A.B., Fagan, A., Daita, K., Heuman, D.M., Zhou, H., Sikaroodi, M., Bajaj, J.S., 2016. Impaired Gut-LiverBrain Axis in Patients with Cirrhosis. Sci. Rep. 6, 26800. https://doi.org/10.1038/srep26800

Ahmad, M.S., Krishnan, S., Ramakrishna, B.S., Mathan, M., Pulimood, A.B., Murthy, S.N., 2000. Butyrate and glucose metabolism by colonocytes in experimental colitis in mice. Gut 46, 4939.

Akira, S., Uematsu, S., Takeuchi, O., 2006. Pathogen recognition and innate immunity. Cell 124, 783-801. https://doi.org/10.1016/j.cell.2006.02.015

Albenberg, L.G., Wu, G.D., 2014. Diet and the intestinal microbiome: associations, functions, and implications for health and disease. Gastroenterology 146, 1564-72. https://doi.org/10.1053/j.gastro.2014.01.058

Augustin, K., Khabbush, A., Williams, S., Eaton, S., Orford, M., Cross, J.H., Heales, S.J.R., Walker, M.C., Williams, R.S.B., 2018. Mechanisms of action for the medium-chain triglyceride ketogenic diet in neurological and metabolic disorders. Lancet Neurol. https://doi.org/10.1016/S1474-4422(17)30408-8

Avoli, M., Louvel, J., Pumain, R., Köhling, R., 2005. Cellular and molecular mechanisms of epilepsy in the human brain. Prog. Neurobiol. 77, 166-200. https://doi.org/10.1016/j.pneurobio.2005.09.006

Bagheri, S., Heydari, A., Alinaghipour, A., Salami, M., 2019. Effect of probiotic supplementation 
on seizure activity and cognitive performance in PTZ-induced chemical kindling. Epilepsy Behav. 95, 43-50. https://doi.org/10.1016/j.yebeh.2019.03.038

Bailey, M.T., Dowd, S.E., Galley, J.D., Hufnagle, A.R., Allen, R.G., Lyte, M., 2011. Exposure to a social stressor alters the structure of the intestinal microbiota: Implications for stressor-induced immunomodulation. Brain. Behav. Immun. 25, 397-407. https://doi.org/10.1016/j.bbi.2010.10.023

Bajaj, J.S., Hylemon, P.B., Ridlon, J.M., Heuman, D.M., Daita, K., White, M.B., Monteith, P., Noble, N.A., Sikaroodi, M., Gillevet, P.M., 2012. Colonic mucosal microbiome differs from stool microbiome in cirrhosis and hepatic encephalopathy and is linked to cognition and inflammation. Am. J. Physiol. Liver Physiol. 303, G675-G685. https://doi.org/10.1152/ajpgi.00152.2012

Bangsgaard Bendtsen, K.M., Krych, L., Sørensen, D.B., Pang, W., Nielsen, D.S., Josefsen, K., Hansen, L.H., Sørensen, S.J., Hansen, A.K., 2012. Gut Microbiota Composition Is Correlated to Grid Floor Induced Stress and Behavior in the BALB/c Mouse. PLoS One 7, e46231. https://doi.org/10.1371/journal.pone.0046231

Bedarf, J.R., Hildebrand, F., Coelho, L.P., Sunagawa, S., Bahram, M., Goeser, F., Bork, P., Wüllner, U., 2017. Functional implications of microbial and viral gut metagenome changes in early stage L-DOPA-naïve Parkinson's disease patients. Genome Med. 9, 39. https://doi.org/10.1186/s13073-017-0428-y

Belkaid, Y., Hand, T.W., 2014. Role of the microbiota in immunity and inflammation. Cell 157, 121-41. https://doi.org/10.1016/j.cell.2014.03.011

Benakis, C., Brea, D., Caballero, S., Faraco, G., Moore, J., Murphy, M., Sita, G., Racchumi, G., Ling, L., Pamer, E.G., Iadecola, C., Anrather, J., 2016. Commensal microbiota affects ischemic stroke outcome by regulating intestinal $\gamma \delta$ T cells. Nat. Med. 22, 516-523. https://doi.org/10.1038/nm.4068

Berer, K., Gerdes, L.A., Cekanaviciute, E., Jia, X., Xiao, L., Xia, Z., Liu, C., Klotz, L., Stauffer, U., 
Baranzini, S.E., Kümpfel, T., Hohlfeld, R., Krishnamoorthy, G., Wekerle, H., 2017. Gut microbiota from multiple sclerosis patients enables spontaneous autoimmune encephalomyelitis in mice. Proc. Natl. Acad. Sci. 114, 10719-10724. https://doi.org/10.1073/pnas.1711233114

Blander, J.M., Longman, R.S., Iliev, I.D., Sonnenberg, G.F., Artis, D., 2017. Regulation of inflammation by microbiota interactions with the host. Nat. Immunol. 18, 851-860. https://doi.org/10.1038/ni.3780

Block, M.L., Zecca, L., Hong, J.-S., 2007. Microglia-mediated neurotoxicity: uncovering the molecular mechanisms. Nat. Rev. Neurosci. 8, 57-69. https://doi.org/10.1038/nrn2038

Boison, D., 2017. New insights into the mechanisms of the ketogenic diet. Curr. Opin. Neurol. 30, 187-192. https://doi.org/10.1097/WCO.0000000000000432

Bolognini, D., Barki, N., Butcher, A.J., Hudson, B.D., Sergeev, E., Molloy, C., Moss, C.E., Bradley, S.J., Le Gouill, C., Bouvier, M., Tobin, A.B., Milligan, G., 2019. Chemogenetics defines receptor-mediated functions of short chain free fatty acids. Nat. Chem. Biol. 15, 489498. https://doi.org/10.1038/s41589-019-0270-1

Bolognini, D., Tobin, A.B., Milligan, G., Moss, C.E., 2016. The Pharmacology and Function of Receptors for Short-Chain Fatty Acids. Mol. Pharmacol. 89, 388-398. https://doi.org/10.1124/mol.115.102301

Borre, Y.E., O’Keeffe, G.W., Clarke, G., Stanton, C., Dinan, T.G., Cryan, J.F., 2014. Microbiota and neurodevelopmental windows: implications for brain disorders. Trends Mol. Med. 20, 509-518. https://doi.org/10.1016/J.MOLMED.2014.05.002

Braakman, H.M.H., van Ingen, J., 2018. Can epilepsy be treated by antibiotics? J. Neurol. 265, 1934-1936. https://doi.org/10.1007/s00415-018-8943-3

Brailoiu, G.C., Oprea, T.I., Zhao, P., Abood, M.E., Brailoiu, E., 2011. Intracellular cannabinoid type 1 (CB1) receptors are activated by anandamide. J. Biol. Chem. 286, 29166-74. https://doi.org/10.1074/jbc.M110.217463 
Braniste, V., Al-Asmakh, M., Kowal, C., Anuar, F., Abbaspour, A., Tóth, M., Korecka, A., Bakocevic, N., Ng, L.G., Guan, N.L., Kundu, P., Gulyás, B., Halldin, C., Hultenby, K., Nilsson, H., Hebert, H., Volpe, B.T., Diamond, B., Pettersson, S., 2014. The gut microbiota influences blood-brain barrier permeability in mice. Sci. Transl. Med. 6, 263ra158. https://doi.org/10.1126/scitranslmed.3009759

Bravo, J.A., Forsythe, P., Chew, M. V., Escaravage, E., Savignac, H.M., Dinan, T.G., Bienenstock, J., Cryan, J.F., 2011. Ingestion of Lactobacillus strain regulates emotional behavior and central GABA receptor expression in a mouse via the vagus nerve. Proc. Natl. Acad. Sci. 108, 1605016055. https://doi.org/10.1073/pnas.1102999108

Burokas, A., Arboleya, S., Moloney, R.D., Peterson, V.L., Murphy, K., Clarke, G., Stanton, C., Dinan, T.G., Cryan, J.F., 2017. Targeting the Microbiota-Gut-Brain Axis: Prebiotics Have Anxiolytic and Antidepressant-like Effects and Reverse the Impact of Chronic Stress in Mice. Biol. Psychiatry 82, 472-487. https://doi.org/10.1016/j.biopsych.2016.12.031

Cabral, G.A., Ferreira, G.A., Jamerson, M.J., 2015. Endocannabinoids and the Immune System in Health and Disease, in: Handbook of Experimental Pharmacology. pp. 185-211. https://doi.org/10.1007/978-3-319-20825-1_6

Cani, P.D., Amar, J., Iglesias, M.A., Poggi, M., Knauf, C., Bastelica, D., Neyrinck, A.M., Fava, F., Tuohy, K.M., Chabo, C., Waget, A., Delmee, E., Cousin, B., Sulpice, T., Chamontin, B., Ferrieres, J., Tanti, J.-F., Gibson, G.R., Casteilla, L., Delzenne, N.M., Alessi, M.C., Burcelin, R., 2007. Metabolic Endotoxemia Initiates Obesity and Insulin Resistance. Diabetes 56, 17611772. https://doi.org/10.2337/db06-1491

Cerri, C., Genovesi, S., Allegra, M., Pistillo, F., Püntener, U., Guglielmotti, A., Perry, V.H., Bozzi, Y., Caleo, M., 2016. The Chemokine CCL2 Mediates the Seizure-enhancing Effects of Systemic Inflammation. J. Neurosci. 36, 3777-3788. https://doi.org/10.1523/JNEUROSCI.0451-15.2016

Chen, Z., Brodie, M.J., Liew, D., Kwan, P., 2017. Treatment Outcomes in Patients With Newly 
Diagnosed Epilepsy Treated With Established and New Antiepileptic Drugs. JAMA Neurol. https://doi.org/10.1001/jamaneurol.2017.3949

Cheung, S.G., Goldenthal, A.R., Uhlemann, A.-C., Mann, J.J., Miller, J.M., Sublette, M.E., 2019. Systematic Review of Gut Microbiota and Major Depression. Front. Psychiatry 10, 34. https://doi.org/10.3389/fpsyt.2019.00034

Ciriaco, M., Ventrice, P., Russo, G., Scicchitano, M., Mazzitello, G., Scicchitano, F., Russo, E., 2013. Corticosteroid-related central nervous system side effects. J. Pharmacol. Pharmacother. https://doi.org/10.4103/0976

Citraro, R., Leo, A., De Caro, C., Nesci, V., Gallo Cantafio, M.E., Amodio, N., Mattace Raso, G., Lama, A., Russo, R., Calignano, A., Tallarico, M., Russo, E., De Sarro, G., 2019. Effects of Histone Deacetylase Inhibitors on the Development of Epilepsy and Psychiatric Comorbidity in WAG/Rij Rats. Mol. Neurobiol. https://doi.org/10.1007/s12035-019-01712-8

Citraro, R., Leo, A., Santoro, M., D’agostino, G., Constanti, A., Russo, E., 2018. Role of Histone Deacetylases (HDACs) in Epilepsy and Epileptogenesis. Curr. Pharm. Des. 23, 5546-5562. https://doi.org/10.2174/1381612823666171024130001

Citraro, R., Scicchitano, F., De Fazio, S., Raggio, R., Mainardi, P., Perucca, E., De Sarro, G., Russo, E., 2011. Preclinical activity profile of $\alpha$-lactoalbumin, a whey protein rich in tryptophan, in rodent models of seizures and epilepsy. Epilepsy Res. 95, 60-69. https://doi.org/10.1016/j.eplepsyres.2011.02.013

Claesson, M.J., Jeffery, I.B., Conde, S., Power, S.E., O’Connor, E.M., Cusack, S., Harris, H.M.B., Coakley, M., Lakshminarayanan, B., O’Sullivan, O., Fitzgerald, G.F., Deane, J., O’Connor, M., Harnedy, N., O’Connor, K., O’Mahony, D., van Sinderen, D., Wallace, M., Brennan, L., Stanton, C., Marchesi, J.R., Fitzgerald, A.P., Shanahan, F., Hill, C., Ross, R.P., O’Toole, P.W., 2012. Gut microbiota composition correlates with diet and health in the elderly. Nature 488, 178-184. https://doi.org/10.1038/nature11319

Clarke, G., Grenham, S., Scully, P., Fitzgerald, P., Moloney, R.D., Shanahan, F., Dinan, T.G., 
Cryan, J.F., 2013. The microbiome-gut-brain axis during early life regulates the hippocampal serotonergic system in a sex-dependent manner. Mol. Psychiatry 18, 666-673. https://doi.org/10.1038/mp.2012.77

Clarke, G., Sandhu, K. V., Griffin, B.T., Dinan, T.G., Cryan, J.F., Hyland, N.P., 2019. Gut Reactions: Breaking Down Xenobiotic-Microbiome Interactions. Pharmacol. Rev. 71, 198224. https://doi.org/10.1124/pr.118.015768

Collins, S.M., Bercik, P., 2009. The relationship between intestinal microbiota and the central nervous system in normal gastrointestinal function and disease. Gastroenterology 136, 200314. https://doi.org/10.1053/j.gastro.2009.01.075

Cryan, J.F., Dinan, T.G., 2019. Talking about a microbiome revolution. Nat. Microbiol. 4, 552-553. https://doi.org/10.1038/s41564-019-0422-9

Cryan, J.F., Dinan, T.G., 2012. Mind-altering microorganisms: The impact of the gut microbiota on brain and behaviour. Nat. Rev. Neurosci. 13, 701-712. https://doi.org/10.1038/nrn3346

Cussotto, S., Strain, C.R., Fouhy, F., Strain, R.G., Peterson, V.L., Clarke, G., Stanton, C., Dinan, T.G., Cryan, J.F., 2018. Differential effects of psychotropic drugs on microbiome composition and gastrointestinal function. Psychopharmacology (Berl). https://doi.org/10.1007/s00213-018$5006-5$

D’Mello, C., Le, T., Swain, M.G., 2009. Cerebral Microglia Recruit Monocytes into the Brain in Response to Tumor Necrosis Factor Signaling during Peripheral Organ Inflammation. J. Neurosci. 29, 2089-2102. https://doi.org/10.1523/jneurosci.3567-08.2009

Dahlin, M., Prast-Nielsen, S., 2019. The gut microbiome and epilepsy. EBioMedicine 44, 741-746. https://doi.org/10.1016/j.ebiom.2019.05.024

David, L.A., Maurice, C.F., Carmody, R.N., Gootenberg, D.B., Button, J.E., Wolfe, B.E., Ling, A. V., Devlin, A.S., Varma, Y., Fischbach, M.A., Biddinger, S.B., Dutton, R.J., Turnbaugh, P.J., 2014. Diet rapidly and reproducibly alters the human gut microbiome. Nature 505, 559-563. https://doi.org/10.1038/nature12820 
De Caro, C., Leo, A., Citraro, R., De Sarro, C., Russo, R., Calignano, A., Russo, E., 2017. The potential role of cannabinoids in epilepsy treatment. Expert Rev. Neurother. 17, 1069-1079. https://doi.org/10.1080/14737175.2017.1373019

De Vadder, F., Kovatcheva-Datchary, P., Goncalves, D., Vinera, J., Zitoun, C., Duchampt, A., Bäckhed, F., Mithieux, G., 2014. Microbiota-generated metabolites promote metabolic benefits via gut-brain neural circuits. Cell 156, 84-96. https://doi.org/10.1016/j.cell.2013.12.016

Del Chierico, F., Vernocchi, P., Dallapiccola, B., Putignani, L., Del Chierico, F., Vernocchi, P., Dallapiccola, B., Putignani, L., 2014. Mediterranean Diet and Health: Food Effects on Gut Microbiota and Disease Control. Int. J. Mol. Sci. 15, 11678-11699. https://doi.org/10.3390/ijms150711678

den Besten, G., van Eunen, K., Groen, A.K., Venema, K., Reijngoud, D.-J., Bakker, B.M., 2013. The role of short-chain fatty acids in the interplay between diet, gut microbiota, and host energy metabolism. J. Lipid Res. 54, 2325-2340. https://doi.org/10.1194/jlr.R036012 den Heijer, J.M., Otte, W.M., van Diessen, E., van Campen, J.S., Lorraine Hompe, E., Jansen, F.E., Joels, M., Braun, K.P.J., Sander, J.W., Zijlmans, M., 2018. The relation between cortisol and functional connectivity in people with and without stress-sensitive epilepsy. Epilepsia 59, 179189. https://doi.org/10.1111/epi.13947

Devinsky, O., Vezzani, A., Najjar, S., De Lanerolle, N.C., Rogawski, M.A., 2013. Glia and epilepsy: Excitability and inflammation. Trends Neurosci. 36, 174-184. https://doi.org/10.1016/j.tins.2012.11.008

Dinan, T.G., Cryan, J.F., 2017. The Microbiome-Gut-Brain Axis in Health and Disease. Gastroenterol. Clin. North Am. 46, 77-89. https://doi.org/10.1016/j.gtc.2016.09.007

DiNuzzo, M., Mangia, S., Maraviglia, B., Giove, F., 2014. Physiological bases of the K+ and the glutamate/GABA hypotheses of epilepsy. Epilepsy Res. 108, 995-1012. https://doi.org/10.1016/j.eplepsyres.2014.04.001

Doenyas, C., 2018. Dietary interventions for autism spectrum disorder: New perspectives from the 
gut-brain axis. Physiol. Behav. 194, 577-582. https://doi.org/10.1016/j.physbeh.2018.07.014

Eid, T., Behar, K., Dhaher, R., Bumanglag, A. V, Lee, T.-S.W., 2012. Roles of glutamine synthetase inhibition in epilepsy. Neurochem. Res. 37, 2339-50. https://doi.org/10.1007/s11064-012-0766-5

Engeli, S., Bohnke, J., Feldpausch, M., Gorzelniak, K., Janke, J., Batkai, S., Pacher, P., HarveyWhite, J., Luft, F.C., Sharma, A.M., Jordan, J., 2005. Activation of the Peripheral Endocannabinoid System in Human Obesity. Diabetes 54, 2838-2843. https://doi.org/10.2337/diabetes.54.10.2838

Erny, D., De Angelis, A.L.H., Jaitin, D., Wieghofer, P., Staszewski, O., David, E., Keren-Shaul, H., Mahlakoiv, T., Jakobshagen, K., Buch, T., Schwierzeck, V., Utermöhlen, O., Chun, E., Garrett, W.S., Mccoy, K.D., Diefenbach, A., Staeheli, P., Stecher, B., Amit, I., Prinz, M., 2015a. Host microbiota constantly control maturation and function of microglia in the CNS. Nat. Neurosci. 18, 965-977. https://doi.org/10.1038/nn.4030

Erny, D., Hrabě de Angelis, A.L., Jaitin, D., Wieghofer, P., Staszewski, O., David, E., Keren-Shaul, H., Mahlakoiv, T., Jakobshagen, K., Buch, T., Schwierzeck, V., Utermöhlen, O., Chun, E., Garrett, W.S., McCoy, K.D., Diefenbach, A., Staeheli, P., Stecher, B., Amit, I., Prinz, M., 2015b. Host microbiota constantly control maturation and function of microglia in the CNS. Nat. Neurosci. 18, 965-77. https://doi.org/10.1038/nn.4030

Everard, A., Belzer, C., Geurts, L., Ouwerkerk, J.P., Druart, C., Bindels, L.B., Guiot, Y., Derrien, M., Muccioli, G.G., Delzenne, N.M., de Vos, W.M., Cani, P.D., 2013. Cross-talk between Akkermansia muciniphila and intestinal epithelium controls diet-induced obesity. Proc. Natl. Acad. Sci. 110, 9066-9071. https://doi.org/10.1073/pnas.1219451110

Finnie, J.W., Manavis, J., Chidlow, G., 2014. Loss of Endothelial Barrier Antigen Immunoreactivity as a Marker of Clostridium perfringens Type D Epsilon Toxin-induced Microvascular Damage in Rat Brain. J. Comp. Pathol. 151, 153-156. https://doi.org/10.1016/j.jcpa.2014.04.010 
Fischer, A., Zalvide, J., Faurobert, E., Albiges-Rizo, C., Tournier-Lasserve, E., 2013. Cerebral cavernous malformations: from CCM genes to endothelial cell homeostasis. Trends Mol. Med. 19, 302-308. https://doi.org/10.1016/j.molmed.2013.02.004

Fisher, R.S., Acevedo, C., Arzimanoglou, A., Bogacz, A., Cross, J.H., Elger, C.E., Engel, J., Forsgren, L., French, J.A., Glynn, M., Hesdorffer, D.C., Lee, B.I., Mathern, G.W., Moshé, S.L., Perucca, E., Scheffer, I.E., Tomson, T., Watanabe, M., Wiebe, S., 2014. ILAE Official Report: A practical clinical definition of epilepsy. Epilepsia 55, 475-482. https://doi.org/10.1111/epi.12550

Fisher, R.S., Van Emde Boas, W., Blume, W., Elger, C., Genton, P., Lee, P., Engel, J., 2005. Epileptic seizures and epilepsy: Definitions proposed by the International League Against Epilepsy (ILAE) and the International Bureau for Epilepsy (IBE). Epilepsia 46, 470-472. https://doi.org/10.1111/j.0013-9580.2005.66104.x

Forsythe, P., 2019. Mast Cells in Neuroimmune Interactions. Trends Neurosci. 42, 43-55. https://doi.org/10.1016/j.tins.2018.09.006

Foss-Feig, J.H., Adkinson, B.D., Ji, J.L., Yang, G., Srihari, V.H., McPartland, J.C., Krystal, J.H., Murray, J.D., Anticevic, A., 2017. Searching for Cross-Diagnostic Convergence: Neural Mechanisms Governing Excitation and Inhibition Balance in Schizophrenia and Autism Spectrum Disorders. Biol. Psychiatry 81, 848-861. https://doi.org/10.1016/j.biopsych.2017.03.005

Foster, J.A., McVey Neufeld, K.-A., 2013. Gut-brain axis: how the microbiome influences anxiety and depression. Trends Neurosci. 36, 305-12. https://doi.org/10.1016/j.tins.2013.01.005

Fritschy, J.-M., 2008. Epilepsy, E/I Balance and GABAA Receptor Plasticity. Front. Mol. Neurosci. 1. https://doi.org/10.3389/NEURO.02.005.2008

Fu, S.-P., Liu, B.-R., Wang, J.-F., Xue, W.-J., Liu, H.-M., Zeng, Y.-L., Huang, B.-X., Li, S.-N., Lv, Q.-K., Wang, W., Liu, J.-X., 2015. $\beta$-Hydroxybutyric Acid Inhibits Growth HormoneReleasing Hormone Synthesis and Secretion Through the GPR109A/Extracellular Signal- 
Regulated 1/2 Signalling Pathway in the Hypothalamus. J. Neuroendocrinol. 27, 212-222. https://doi.org/10.1111/jne.12256

Furness, J.B. (Ed.), 2007. The Enteric Nervous System. Blackwell Publishing, Malden,

Massachusetts, USA. https://doi.org/10.1002/9780470988756

Geuking, M.B., Cahenzli, J., Lawson, M.A.E., Ng, D.C.K., Slack, E., Hapfelmeier, S., McCoy, K.D., Macpherson, A.J., 2011. Intestinal Bacterial Colonization Induces Mutualistic Regulatory T Cell Responses. Immunity 34, 794-806. https://doi.org/10.1016/j.immuni.2011.03.021

Gómez-Eguílaz, M., Ramón-Trapero, J.L., Pérez-Martínez, L., Blanco, J.R., 2018. The beneficial effect of probiotics as a supplementary treatment in drug-resistant epilepsy: a pilot study. Benef. Microbes 9, 875-881. https://doi.org/10.3920/BM2018.0018

Gronier, B., Savignac, H.M., Miceli, M. Di, Idriss, S.M., Tzortzis, G., Anthony, D., Burnet, P.W.J., 2018. Increased cortical neuronal responses to NMDA and improved attentional set-shifting performance in rats following prebiotic (B-GOS®) ingestion. Eur. Neuropsychopharmacol. 28, 211. https://doi.org/10.1016/J.EURONEURO.2017.11.001

He, Z., Cui, B.T., Zhang, T., Li, P., Long, C.Y., Ji, G.Z., Zhang, F.M., 2017. Fecal microbiota transplantation cured epilepsy in a case with Crohn's Disease: The first report. World J. Gastroenterol. 23, 3565-3568. https://doi.org/10.3748/wjg.v23.i19.3565

Healey, G.R., Murphy, R., Brough, L., Butts, C.A., Coad, J., 2017. Interindividual variability in gut microbiota and host response to dietary interventions. Nutr. Rev. 75, 1059-1080. https://doi.org/10.1093/nutrit/nux062

Heijtz, R.D., Wang, S., Anuar, F., Qian, Y., Bjorkholm, B., Samuelsson, A., Hibberd, M.L., Forssberg, H., Pettersson, S., 2011. Normal gut microbiota modulates brain development and behavior. Proc. Natl. Acad. Sci. 108, 3047-3052. https://doi.org/10.1073/pnas.1010529108 Henshall, D.C., Kobow, K., 2015. Epigenetics and epilepsy. Cold Spring Harb. Perspect. Med. 5, 210. https://doi.org/10.1101/cshperspect.a022731 
Ho, L., Ono, K., Tsuji, M., Mazzola, P., Singh, R., Pasinetti, G.M., 2018. Protective roles of intestinal microbiota derived short chain fatty acids in Alzheimer's disease-type beta-amyloid neuropathological mechanisms. Expert Rev. Neurother. 18, 83-90.

https://doi.org/10.1080/14737175.2018.1400909

Ho, Y.-H., Lin, Y.-T., Wu, C.-W.J., Chao, Y.-M., Chang, A.Y.W., Chan, J.Y.H., 2015. Peripheral inflammation increases seizure susceptibility via the induction of neuroinflammation and oxidative stress in the hippocampus. J. Biomed. Sci. 22, 46. https://doi.org/10.1186/s12929015-0157-8

Hoban, A.E., Stilling, R.M., Ryan, F.J., Shanahan, F., Dinan, T.G., Claesson, M.J., Clarke, G., Cryan, J.F., 2016. Regulation of prefrontal cortex myelination by the microbiota. Transl. Psychiatry 6, e774-e774. https://doi.org/10.1038/tp.2016.42

Holzer, P., 2016. Neuropeptides, Microbiota, and Behavior. Int. Rev. Neurobiol. 131, 67-89. https://doi.org/10.1016/bs.irn.2016.08.005

Horder, J., Petrinovic, M.M., Mendez, M.A., Bruns, A., Takumi, T., Spooren, W., Barker, G.J., Künnecke, B., Murphy, D.G., 2018. Glutamate and GABA in autism spectrum disorder-a translational magnetic resonance spectroscopy study in man and rodent models. Transl. Psychiatry 8, 106. https://doi.org/10.1038/s41398-018-0155-1

Hsiao, E.Y., McBride, S.W., Hsien, S., Sharon, G., Hyde, E.R., McCue, T., Codelli, J.A., Chow, J., Reisman, S.E., Petrosino, J.F., Patterson, P.H., Mazmanian, S.K., 2013. Microbiota Modulate Behavioral and Physiological Abnormalities Associated with Neurodevelopmental Disorders. Cell 155, 1451-1463. https://doi.org/10.1016/j.cell.2013.11.024

Hu, Y., Phelan, V., Ntai, I., Farnet, C.M., Zazopoulos, E., Bachmann, B.O., 2007. Benzodiazepine Biosynthesis in Streptomyces refuineus. Chem. Biol. 14, 691-701. https://doi.org/10.1016/j.chembiol.2007.05.009

Hugon, P., Dufour, J.-C., Colson, P., Fournier, P.-E., Sallah, K., Raoult, D., 2015. A comprehensive repertoire of prokaryotic species identified in human beings. Lancet Infect. Dis. 15, 1211- 
1219. https://doi.org/10.1016/S1473-3099(15)00293-5

Iannone, L.F., Preda, A., Blottière, H.M., Clarke, G., Albani, D., Belcastro, V., Carotenuto, M., Cattaneo, A., Citraro, R., Ferraris, C., Ronchi, F., Luongo, G., Santocchi, E., Guiducci, L., Baldelli, P., Iannetti, P., Pedersen, S., Petretto, A., Provasi, S., Selmer, K., Spalice, A., Tagliabue, A., Verrotti, A., Segata, N., Zimmermann, J., Minetti, C., Mainardi, P., Giordano, C., Sisodiya, S., Zara, F., Russo, E., Striano, P., 2019. Microbiota-gut brain axis involvement in neuropsychiatric disorders. Expert Rev. Neurother. 1-14. https://doi.org/10.1080/14737175.2019.1638763

Ivanov, I.I., Atarashi, K., Manel, N., Brodie, E.L., Shima, T., Karaoz, U., Wei, D., Goldfarb, K.C., Santee, C.A., Lynch, S. V., Tanoue, T., Imaoka, A., Itoh, K., Takeda, K., Umesaki, Y., Honda, K., Littman, D.R., 2009. Induction of Intestinal Th17 Cells by Segmented Filamentous Bacteria. Cell 139, 485-498. https://doi.org/10.1016/j.cell.2009.09.033

Izzo, A.A., Piscitelli, F., Capasso, R., Aviello, G., Romano, B., Borrelli, F., Petrosino, S., Di Marzo, V., 2009. Peripheral endocannabinoid dysregulation in obesity: relation to intestinal motility and energy processing induced by food deprivation and re-feeding. Br. J. Pharmacol. 158, 451-461. https://doi.org/10.1111/j.1476-5381.2009.00183.x

J.S., B., 2014. The role of microbiota in hepatic encephalopathy. Gut Microbes 5, 397-403. https://doi.org/10.4161/gmic.28684

Jandhyala, S.M., Talukdar, R., Subramanyam, C., Vuyyuru, H., Sasikala, M., Reddy, D.N., 2015. Role of the normal gut microbiota. World J. Gastroenterol. 21, 8836-8847. https://doi.org/10.3748/wjg.v21.i29.8787

Janik, R., Thomason, L.A.M., Stanisz, A.M., Forsythe, P., Bienenstock, J., Stanisz, G.J., 2016. Magnetic resonance spectroscopy reveals oral Lactobacillus promotion of increases in brain GABA, N-acetyl aspartate and glutamate. Neuroimage 125, 988-995. https://doi.org/10.1016/j.neuroimage.2015.11.018

Karst, H., 1999. Episodic corticosterone treatment accelerates kindling epileptogenesis and triggers 
long-term changes in hippocampal CA1 cells, in the fully kindled state. Eur. J. Neurosci. 11, 889-898. https://doi.org/10.1046/j.1460-9568.1999.00495.x

KITAMURA, S., SUGIHARA, K., KUWASAKO, M., TATSUMI, K., 1997. The Role of Mammalian Intestinal Bacteria in the Reductive Metabolism of Zonisamide. J. Pharm. Pharmacol. 49, 253-256. https://doi.org/10.1111/j.2042-7158.1997.tb06790.x

Klein, M.S., Newell, C., Bomhof, M.R., Reimer, R.A., Hittel, D.S., Rho, J.M., Vogel, H.J., Shearer, J., 2016. Metabolomic Modeling to Monitor Host Responsiveness to Gut Microbiota Manipulation in the BTBRT+tf/j Mouse. J. Proteome Res. 15, 1143-1150. https://doi.org/10.1021/acs.jproteome.5b01025

Kowiański, P., Lietzau, G., Czuba, E., Waśkow, M., Steliga, A., Moryś, J., 2018. BDNF: A Key Factor with Multipotent Impact on Brain Signaling and Synaptic Plasticity. Cell. Mol. Neurobiol. 38, 579-593. https://doi.org/10.1007/s10571-017-0510-4

Lee, E., Lee, J., Kim, E., 2017. Excitation/Inhibition Imbalance in Animal Models of Autism Spectrum Disorders. Biol. Psychiatry 81, 838-847. https://doi.org/10.1016/J.BIOPSYCH.2016.05.011

Lee, R.W.Y., Corley, M.J., Pang, A., Arakaki, G., Abbott, L., Nishimoto, M., Miyamoto, R., Lee, E., Yamamoto, S., Maunakea, A.K., Lum-Jones, A., Wong, M., 2018. A modified ketogenic gluten-free diet with MCT improves behavior in children with autism spectrum disorder. Physiol. Behav. 188, 205-211. https://doi.org/10.1016/j.physbeh.2018.02.006

Lee, Y.K., Menezes, J.S., Umesaki, Y., Mazmanian, S.K., 2011. Proinflammatory T-cell responses to gut microbiota promote experimental autoimmune encephalomyelitis. Proc. Natl. Acad. Sci. 108, 4615-4622. https://doi.org/10.1073/pnas.1000082107

Liang, L., Zhou, H., Zhang, S., Yuan, J., Wu, H., 2017. E ff ects of gut microbiota disturbance induced in early life on the expression of extrasynaptic GABA-A receptor $\alpha 5$ and $\delta$ subunits in the hippocampus of adult rats. Brain Res. Bull. 135, 113-119. https://doi.org/10.1016/j.brainresbull.2017.09.014 
Liang, X., Bushman, F.D., FitzGerald, G.A., 2015. Rhythmicity of the intestinal microbiota is regulated by gender and the host circadian clock. Proc. Natl. Acad. Sci. 112, 10479-10484. https://doi.org/10.1073/pnas.1501305112

Lindefeldt, M., Eng, A., Darban, H., Bjerkner, A., Zetterström, C.K., Allander, T., Andersson, B., Borenstein, E., Dahlin, M., Prast-Nielsen, S., 2019a. The ketogenic diet influences taxonomic and functional composition of the gut microbiota in children with severe epilepsy. npj Biofilms Microbiomes 5, 5. https://doi.org/10.1038/s41522-018-0073-2

Lindefeldt, M., Eng, A., Darban, H., Bjerkner, A., Zetterström, C.K., Allander, T., Andersson, B., Borenstein, E., Dahlin, M., Prast-Nielsen, S., 2019b. The ketogenic diet influences taxonomic and functional composition of the gut microbiota in children with severe epilepsy. npj Biofilms Microbiomes 5, 5. https://doi.org/10.1038/s41522-018-0073-2

Liu, F., Li, J., Wu, F., Zheng, H., Peng, Q., Zhou, H., 2019. Altered composition and function of intestinal microbiota in autism spectrum disorders: a systematic review. Transl. Psychiatry 9 , 43. https://doi.org/10.1038/s41398-019-0389-6

Lum, G.R., Olson, C.A., Hsiao, E.Y., 2019. Emerging roles for the intestinal microbiome in epilepsy. Neurobiol. Dis. 104576. https://doi.org/10.1016/J.NBD.2019.104576

Luscher, B., Fuchs, T., 2015. GABAergic Control of Depression-Related Brain States, in: Advances in Pharmacology (San Diego, Calif.). pp. 97-144. https://doi.org/10.1016/bs.apha.2014.11.003

Lutas, A., Yellen, G., 2013. The ketogenic diet: metabolic influences on brain excitability and epilepsy. Trends Neurosci. 36, 32-40. https://doi.org/10.1016/j.tins.2012.11.005

Ma, Q., Xing, C., Long, W., Wang, H.Y., Liu, Q., Wang, R.-F., 2019. Impact of microbiota on central nervous system and neurological diseases: the gut-brain axis. J. Neuroinflammation 16, 53. https://doi.org/10.1186/s12974-019-1434-3

Maguire, J., Salpekar, J.A., 2013. Stress, seizures, and hypothalamic-pituitary-adrenal axis targets for the treatment of epilepsy. Epilepsy Behav. 26, 352-62. https://doi.org/10.1016/j.yebeh.2012.09.040 
Maier, L., Pruteanu, M., Kuhn, M., Zeller, G., Telzerow, A., Anderson, E.E., Brochado, A.R., Fernandez, K.C., Dose, H., Mori, H., Patil, K.R., Bork, P., Typas, A., 2018a. Extensive impact of non-antibiotic drugs on human gut bacteria. Nature 555, 623-628. https://doi.org/10.1038/nature25979

Maier, L., Pruteanu, M., Kuhn, M., Zeller, G., Telzerow, A., Anderson, E.E., Brochado, A.R., Fernandez, K.C., Dose, H., Mori, H., Patil, K.R., Bork, P., Typas, A., 2018b. Extensive impact of non-antibiotic drugs on human gut bacteria. Nature 555, 623-628. https://doi.org/10.1038/nature25979

Marchi, N., Angelov, L., Masaryk, T., Fazio, V., Granata, T., Hernandez, N., Hallene, K., Diglaw, T., Franic, L., Najm, I., Janigro, D., 2007. Seizure-Promoting Effect of Blood?Brain Barrier Disruption. Epilepsia 48, 732-742. https://doi.org/10.1111/j.1528-1167.2007.00988.x

Marchi, N., Granata, T., Janigro, D., 2014. Inflammatory pathways of seizure disorders. Trends Neurosci. 37, 55-65. https://doi.org/10.1016/j.tins.2013.11.002

Maslowski, K.M., Mackay, C.R., 2011. Diet, gut microbiota and immune responses. Nat. Immunol. 12, 5-9. https://doi.org/10.1038/ni0111-5

Mayer, E.A., 2011. Gut feelings: the emerging biology of gut-brain communication. https://doi.org/10.1038/nrn3071

Mayer, E.A., 2000. The neurobiology of stress and gastrointestinal disease. Gut 47, 861-9.

Mayer, E.A., Tillisch, K., Gupta, A., 2015. Gut/brain axis and the microbiota. J. Clin. Invest. 125, 926-938. https://doi.org/10.1172/JCI76304

Mehrpouya-Bahrami, P., Chitrala, K.N., Ganewatta, M.S., Tang, C., Murphy, E.A., Enos, R.T., Velazquez, K.T., McCellan, J., Nagarkatti, M., Nagarkatti, P., 2017. Blockade of CB1 cannabinoid receptor alters gut microbiota and attenuates inflammation and diet-induced obesity. Sci. Rep. 7, 15645. https://doi.org/10.1038/s41598-017-15154-6

Mika, A., Gaffney, M., Roller, R., Hills, A., Bouchet, C.A., Hulen, K.A., Thompson, R.S., Chichlowski, M., Berg, B.M., Fleshner, M., 2018. Feeding the developing brain: Juvenile rats 
fed diet rich in prebiotics and bioactive milk fractions exhibit reduced anxiety-related behavior and modified gene expression in emotion circuits. Neurosci. Lett. 677, 103-109. https://doi.org/10.1016/j.neulet.2018.01.052

Mittal, R., Debs, L.H., Patel, A.P., Nguyen, D., Patel, K., O’Connor, G., Grati, M., Mittal, J., Yan, D., Eshraghi, A.A., Deo, S.K., Daunert, S., Liu, X.Z., 2017. Neurotransmitters: The Critical Modulators Regulating Gut-Brain Axis. J. Cell. Physiol. 232, 2359-2372. https://doi.org/10.1002/jcp.25518

Moratalla, A., Ampuero, J., Bellot, P., Gallego-Durán, R., Zapater, P., Roger, M., Figueruela, B., Martínez-Moreno, B., González-Navajas, J.M., Such, J., Romero-Gómez, M., Francés, R., 2017. Lactulose reduces bacterial DNA translocation, which worsens neurocognitive shape in cirrhotic patients with minimal hepatic encephalopathy. Liver Int. 37, 212-223. https://doi.org/10.1111/liv.13200

Mowat, A.M., Agace, W.W., 2014. Regional specialization within the intestinal immune system. Nat. Rev. Immunol. 14, 667-685. https://doi.org/10.1038/nri3738

Muccioli, G.G., Naslain, D., Bäckhed, F., Reigstad, C.S., Lambert, D.M., Delzenne, N.M., Cani, P.D., 2010. The endocannabinoid system links gut microbiota to adipogenesis. Mol. Syst. Biol. 6, 392. https://doi.org/10.1038/msb.2010.46

Mueller, Noel T, Bakacs, E., Combellick, J., Grigoryan, Z., Dominguez-Bello, M.G., 2015. The infant microbiome development: mom matters. Trends Mol. Med. 21, 109-17. https://doi.org/10.1016/j.molmed.2014.12.002

Mueller, Noel T., Bakacs, E., Combellick, J., Grigoryan, Z., Dominguez-Bello, M.G., 2015. The infant microbiome development: Mom matters. Trends Mol. Med. 21, 109-117. https://doi.org/10.1016/j.molmed.2014.12.002

Murta, V., Farías, M.I., Pitossi, F.J., Ferrari, C.C., 2015. Chronic systemic IL-1 $\beta$ exacerbates central neuroinflammation independently of the blood-brain barrier integrity. J. Neuroimmunol. 278, 30-43. https://doi.org/10.1016/j.jneuroim.2014.11.023 
Naia, L., Cunha-Oliveira, T., Rodrigues, J., Rosenstock, T.R., Oliveira, A., Ribeiro, M., Carmo, C., Oliveira-Sousa, S.I., Duarte, A.I., Hayden, M.R., Rego, A.C., 2017. Histone Deacetylase Inhibitors Protect Against Pyruvate Dehydrogenase Dysfunction in Huntington’s Disease. J. Neurosci. 37, 2776-2794. https://doi.org/10.1523/JNEUROSCI.2006-14.2016

Newell, C., Bomhof, M.R., Reimer, R.A., Hittel, D.S., Rho, J.M., Shearer, J., 2016. Ketogenic diet modifies the gut microbiota in a murine model of autism spectrum disorder. Mol. Autism 7. https://doi.org/10.1186/s13229-016-0099-3

Nutsch, K., Chai, J.N., Ai, T.L., Russler-Germain, E., Feehley, T., Nagler, C.R., Hsieh, C.-S., 2016. Rapid and Efficient Generation of Regulatory T Cells to Commensal Antigens in the Periphery. Cell Rep. 17, 206-220. https://doi.org/10.1016/j.celrep.2016.08.092

O’Mahony, S.M., Marchesi, J.R., Scully, P., Codling, C., Ceolho, A.-M., Quigley, E.M.M., Cryan, J.F., Dinan, T.G., 2009. Early life stress alters behavior, immunity, and microbiota in rats: implications for irritable bowel syndrome and psychiatric illnesses. Biol. Psychiatry 65, 263-7. https://doi.org/10.1016/j.biopsych.2008.06.026

Obermeier, B., Daneman, R., Ransohoff, R.M., 2013. Development, maintenance and disruption of the blood-brain barrier. Nat. Med. 19, 1584-96. https://doi.org/10.1038/nm.3407

Oby, E., Janigro, D., 2006. The Blood?Brain Barrier and Epilepsy. Epilepsia 47, 1761-1774. https://doi.org/10.1111/j.1528-1167.2006.00817.x

Ohland, C.L., MacNaughton, W.K., 2010. Probiotic bacteria and intestinal epithelial barrier function. Am. J. Physiol. Liver Physiol. 298, G807-G819. https://doi.org/10.1152/ajpgi.00243.2009

Olson, C.A., Vuong, H.E., Yano, J.M., Liang, Q.Y., Nusbaum, D.J., Hsiao, E.Y., 2018. The Gut Microbiota Mediates the Anti-Seizure Effects of the Ketogenic Diet. Cell 173, 1728-1741.e13. https://doi.org/10.1016/j.cell.2018.04.027

Peng, A., Qiu, X., Lai, W., Li, W., Zhang, L., Zhu, X., He, S., Duan, J., Chen, L., 2018. Altered composition of the gut microbiome in patients with drug-resistant epilepsy. Epilepsy Res. 147, 
102-107. https://doi.org/10.1016/j.eplepsyres.2018.09.013

Pertwee, R.G., 2006. The pharmacology of cannabinoid receptors and their ligands: An overview. Int. J. Obes. 30, S13-S18. https://doi.org/10.1038/sj.ijo.0803272

Pitkänen, A., Lukasiuk, K., Edward Dudek, F., Staley, K.J., 2015. Epileptogenesis. Cold Spring Harb. Perspect. Med. 5. https://doi.org/10.1101/cshperspect.a022822

Pituch-Zdanowska, A., Banaszkiewicz, A., Albrecht, P., 2015. The role of dietary fibre in inflammatory bowel disease. Prz. Gastroenterol. 10, 135-41. https://doi.org/10.5114/pg.2015.52753

Prenderville, J.A., Kennedy, P.J., Dinan, T.G., Cryan, J.F., 2015. Adding fuel to the fire: the impact of stress on the ageing brain. Trends Neurosci. 38, 13-25.

Pritchard, P.B., Wannamaker, B.B., Sagel, J., Daniel, C.M., 1985. Serum prolactin and cortisol levels in evaluation of pseudoepileptic seizures. Ann. Neurol. 18, 87-9. https://doi.org/10.1002/ana.410180115

Qin, J., Li, R., Raes, J., Arumugam, M., Burgdorf, K.S., Manichanh, C., Nielsen, T., Pons, N., Levenez, F., Yamada, T., Mende, D.R., Li, J., Xu, J., Li, Shaochuan, Li, D., Cao, J., Wang, B., Liang, H., Zheng, H., Xie, Y., Tap, J., Lepage, P., Bertalan, M., Batto, J.-M., Hansen, T., Le Paslier, D., Linneberg, A., Nielsen, H.B., Pelletier, E., Renault, P., Sicheritz-Ponten, T., Turner, K., Zhu, H., Yu, C., Li, Shengting, Jian, M., Zhou, Y., Li, Y., Zhang, X., Li, Songgang, Qin, N., Yang, H., Wang, Jian, Brunak, S., Doré, J., Guarner, F., Kristiansen, K., Pedersen, O., Parkhill, J., Weissenbach, J., Bork, P., Ehrlich, S.D., Wang, Jun, Wang, Jun, 2010. A human gut microbial gene catalogue established by metagenomic sequencing. Nature 464, 59-65. https://doi.org/10.1038/nature08821

Quan, N., 2008. Immune-To-Brain Signaling: How Important are the Blood-Brain Barrierindependent Pathways? Why Does CNS Need to Sense Immunological Activity? Mol Neurobiol 37, 142-152. https://doi.org/10.1007/s12035-008-8026-Z

Qureshi, I.A., Mehler, M.F., 2010. Epigenetic mechanisms underlying human epileptic disorders 
and the process of epileptogenesis. Neurobiol. Dis. 39, 53-60.

https://doi.org/10.1016/j.nbd.2010.02.005

Rao, M., Gershon, M.D., 2016. The bowel and beyond: the enteric nervous system in neurological disorders. Nat. Rev. Gastroenterol. Hepatol. 13, 517-528.

https://doi.org/10.1038/nrgastro.2016.107

REED, C.A.L., 1916. THE BACILLUS EPILEPTICUS. J. Am. Med. Assoc. LXVI, 1607. https://doi.org/10.1001/jama.1916.02580470017009

Riazi, K., Galic, M.A., Kuzmiski, J.B., Ho, W., Sharkey, K.A., Pittman, Q.J., 2008. Microglial activation and TNF production mediate altered CNS excitability following peripheral inflammation. Proc. Natl. Acad. Sci. 105, 17151-17156.

https://doi.org/10.1073/pnas.0806682105

Riazi, K., Galic, M.A., Pittman, Q.J., 2010. Contributions of peripheral inflammation to seizure susceptibility: Cytokines and brain excitability. Epilepsy Res. 89, 34-42. https://doi.org/10.1016/j.eplepsyres.2009.09.004

Riazi, K., Honar, H., Homayoun, H., Demehri, S., Bahadori, M., Dehpour, A.R., 2004. Intestinal inflammation alters the susceptibility to pentylenetetrazole-induced seizure in mice. J. Gastroenterol. Hepatol. 19, 270-7.

Richard, M.L., Sokol, H., n.d. The gut mycobiota: insights into analysis, environmental interactions and role in gastrointestinal diseases. https://doi.org/10.1038/s41575-019-0121-2

Roberts, A.J., Keith, L.D., 1994. Mineralocorticoid receptors mediate the enhancing effects of corticosterone on convulsion susceptibility in mice. J. Pharmacol. Exp. Ther. 270, 505-11.

Rodríguez, J.M., Murphy, K., Stanton, C., Ross, R.P., Kober, O.I., Juge, N., Avershina, E., Rudi, K., Narbad, A., Jenmalm, M.C., Marchesi, J.R., Collado, M.C., 2015a. The composition of the gut microbiota throughout life, with an emphasis on early life. Microb. Ecol. Health Dis. 26, 26050. https://doi.org/10.3402/mehd.v26.26050

Rodríguez, J.M., Murphy, K., Stanton, C., Ross, R.P., Kober, O.I., Juge, N., Avershina, E., Rudi, 
K., Narbad, A., Jenmalm, M.C., Marchesi, J.R., Collado, M.C., 2015b. The composition of the gut microbiota throughout life, with an emphasis on early life. Microb. Ecol. Heal. Dis. 26, 26050. https://doi.org/10.3402/mehd.v26.26050

Rooks, M.G., Garrett, W.S., 2016. Gut microbiota, metabolites and host immunity. Nat. Rev. Immunol. 16, 341-352. https://doi.org/10.1038/nri.2016.42

Roshchina, V. V, n.d. 2.2 Occurrence of Neurotransmitters in Living Organisms 2.2.1 Discoveries. Round, J.L., Lee, S.M., Li, J., Tran, G., Jabri, B., Chatila, T.A., Mazmanian, S.K., 2011. The TollLike Receptor 2 Pathway Establishes Colonization by a Commensal of the Human Microbiota. Science (80-. ). 332, 974-977. https://doi.org/10.1126/science.1206095

Round, J.L., Mazmanian, S.K., 2009. The gut microbiota shapes intestinal immune responses during health and disease. Nat. Rev. Immunol. 9, 313-323. https://doi.org/10.1038/nri2515

Rousseaux, C., Thuru, X., Gelot, A., Barnich, N., Neut, C., Dubuquoy, L., Dubuquoy, C., Merour, E., Geboes, K., Chamaillard, M., Ouwehand, A., Leyer, G., Carcano, D., Colombel, J.-F., Ardid, D., Desreumaux, P., 2007. Lactobacillus acidophilus modulates intestinal pain and induces opioid and cannabinoid receptors. Nat. Med. 13, 35-37. https://doi.org/10.1038/nm1521

Russell, W.R., Gratz, S.W., Duncan, S.H., Holtrop, G., Ince, J., Scobbie, L., Duncan, G., Johnstone, A.M., Lobley, G.E., Wallace, R.J., Duthie, G.G., Flint, H.J., 2011. High-protein, reducedcarbohydrate weight-loss diets promote metabolite profiles likely to be detrimental to colonic health. Am. J. Clin. Nutr. 93, 1062-1072. https://doi.org/10.3945/ajcn.110.002188

Russo, R., De Caro, C., Avagliano, C., Cristiano, C., La Rana, G., Mattace Raso, G., Berni Canani, R., Meli, R., Calignano, A., 2016. Sodium butyrate and its synthetic amide derivative modulate nociceptive behaviors in mice. Pharmacol. Res. 103, 279-91. https://doi.org/10.1016/j.phrs.2015.11.026

Sampson, T.R., Debelius, J.W., Thron, T., Janssen, S., Shastri, G.G., Ilhan, Z.E., Challis, C., Schretter, C.E., Rocha, S., Gradinaru, V., Chesselet, M.F., Keshavarzian, A., Shannon, K.M., 
Krajmalnik-Brown, R., Wittung-Stafshede, P., Knight, R., Mazmanian, S.K., 2016. Gut Microbiota Regulate Motor Deficits and Neuroinflammation in a Model of Parkinson's Disease. Cell 167, 1469-1480.e12. https://doi.org/10.1016/j.cell.2016.11.018

Sánchez-Villegas, A., Henríquez, P., Bes-Rastrollo, M., Doreste, J., 2006. Mediterranean diet and depression. Public Health Nutr. 9, 1104-1109. https://doi.org/10.1017/S1368980007668578

Sarris, J., Logan, A.C., Akbaraly, T.N., Amminger, G.P., Balanzá-Martínez, V., Freeman, M.P., Hibbeln, J., Matsuoka, Y., Mischoulon, D., Mizoue, T., Nanri, A., Nishi, D., Ramsey, D., Rucklidge, J.J., Sanchez-Villegas, A., Scholey, A., Su, K.-P., Jacka, F.N., 2015. Nutritional medicine as mainstream in psychiatry. The Lancet Psychiatry 2, 271-274. https://doi.org/10.1016/S2215-0366(14)00051-0

Schatzberg, A.F., Keller, J., Tennakoon, L., Lembke, A., Williams, G., Kraemer, F.B., Sarginson, J.E., Lazzeroni, L.C., Murphy, G.M., 2014. HPA axis genetic variation, cortisol and psychosis in major depression. Mol. Psychiatry 19, 220-227. https://doi.org/10.1038/mp.2013.129

Schridde, U., Van Luijtelaar, G., 2004. Corticosterone increases spike-wave discharges in a doseand time-dependent manner in WAG/Rij rats. Pharmacol. Biochem. Behav. 78, 369-375. https://doi.org/10.1016/j.pbb.2004.04.012

Schwarzer, M., Hermanova, P., Srutkova, D., Golias, J., Hudcovic, T., Zwicker, C., Sinkora, M., Akgün, J., Wiedermann, U., Tuckova, L., Kozakova, H., Schabussova, I., 2019. Germ-Free Mice Exhibit Mast Cells With Impaired Functionality and Gut Homing and Do Not Develop Food Allergy. Front. Immunol. 10, 205. https://doi.org/10.3389/fimmu.2019.00205

Sender, R., Fuchs, S., Milo, R., 2016. Revised Estimates for the Number of Human and Bacteria Cells in the Body. PLOS Biol. 14, e1002533. https://doi.org/10.1371/journal.pbio.1002533

Sharon, G., Sampson, T.R., Geschwind, D.H., Mazmanian, S.K., 2016. The Central Nervous System and the Gut Microbiome. Cell 167, 915-932. https://doi.org/10.1016/j.cell.2016.10.027 Sherwin, E., Dinan, T.G., Cryan, J.F., 2018. Recent developments in understanding the role of the gut microbiota in brain health and disease. Ann. N. Y. Acad. Sci. 1420, 5-25. 
https://doi.org/10.1111/nyas.13416

Shifrin, D.A., McConnell, R.E., Nambiar, R., Higginbotham, J.N., Coffey, R.J., Tyska, M.J., 2012. Enterocyte Microvillus-Derived Vesicles Detoxify Bacterial Products and Regulate EpithelialMicrobial Interactions. Curr. Biol. 22, 627-631. https://doi.org/10.1016/j.cub.2012.02.022

Simeoli, R., Mattace Raso, G., Pirozzi, C., Lama, A., Santoro, A., Russo, R., Montero-Melendez, T., Berni Canani, R., Calignano, A., Perretti, M., Meli, R., 2017. An orally administered butyrate-releasing derivative reduces neutrophil recruitment and inflammation in dextran sulphate sodium-induced murine colitis. Br. J. Pharmacol. 174, 1484-1496. https://doi.org/10.1111/bph.13637

Singh, R.K., Chang, H.-W., Yan, D., Lee, K.M., Ucmak, D., Wong, K., Abrouk, M., Farahnik, B., Nakamura, M., Zhu, T.H., Bhutani, T., Liao, W., 2017. Influence of diet on the gut microbiome and implications for human health. J. Transl. Med. 15, 73. https://doi.org/10.1186/s12967-017-1175-y

Smith, K., McCoy, K.D., Macpherson, A.J., 2007. Use of axenic animals in studying the adaptation of mammals to their commensal intestinal microbiota. Semin. Immunol. 19, 59-69. https://doi.org/10.1016/J.SMIM.2006.10.002

Smith, P.M., Howitt, M.R., Panikov, N., Michaud, M., Gallini, C.A., Bohlooly-Y, M., Glickman, J.N., Garrett, W.S., 2013. The Microbial Metabolites, Short-Chain Fatty Acids, Regulate Colonic Treg Cell Homeostasis. Science (80-. ). 341, 569-573. https://doi.org/10.1126/science.1241165

Sohal, V.S., Rubenstein, J.L.R., 2019. Excitation-inhibition balance as a framework for investigating mechanisms in neuropsychiatric disorders. Mol. Psychiatry 1. https://doi.org/10.1038/s41380-019-0426-0

Spiller, A.E., Guberman, A., Bartolomei, F., Zifkin, B., Andermann, F., 2005. Epileptogenesis due to peripheral injury as a cause of focal epilepsy. Epilepsia 46, 1252-1255. https://doi.org/10.1111/j.1528-1167.2005.59504.x 
Stanton, C., Sandhu, K. V, Sherwin, E., Et, H., Dinan, T.G., Cryan, J.F., 2016. Feeding the microbiota-gut-brain axis : diet, microbiome, and neuropsychiatry 223-244. https://doi.org/10.1016/j.trs1.2016.10.002

Starke, R.M., McCarthy, D.J., Komotar, R.J., Connolly, E.S., 2017. Gut Microbiome and Endothelial TLR4 Activation Provoke Cerebral Cavernous Malformations. Neurosurgery 81, N44-N46. https://doi.org/10.1093/neuros/nyx450

Stilling, R.M., van de Wouw, M., Clarke, G., Stanton, C., Dinan, T.G., Cryan, J.F., 2016. The neuropharmacology of butyrate: The bread and butter of the microbiota-gut-brain axis? Neurochem. Int. 99, 110-132. https://doi.org/10.1016/j.neuint.2016.06.011

Stokes, J.M., Davis, J.H., Mangat, C.S., Williamson, J.R., Brown, E.D., 2014. Discovery of a small molecule that inhibits bacterial ribosome biogenesis. Elife 3, e03574. https://doi.org/10.7554/eLife.03574

Sudo, N., Chida, Y., Aiba, Y., Sonoda, J., Oyama, N., Yu, X.-N., Kubo, C., Koga, Y., 2004a. Postnatal microbial colonization programs the hypothalamic-pituitary-adrenal system for stress response in mice. J. Physiol. 558, 263-275. https://doi.org/10.1113/jphysiol.2004.063388

Sudo, N., Chida, Y., Aiba, Y., Sonoda, J., Oyama, N., Yu, X.N., Kubo, C., Koga, Y., 2004b. Postnatal microbial colonization programs the hypothalamic-pituitary-adrenal system for stress response in mice. J. Physiol. 558, 263-275. https://doi.org/10.1113/jphysiol.2004.063388

Suraweera, D., Sundaram, V., Saab, S., 2016. Evaluation and Management of Hepatic Encephalopathy: Current Status and Future Directions. Gut Liver 10, 509-519. https://doi.org/10.5009/gnl15419

Sutter, R., Rüegg, S., Tschudin-Sutter, S., 2015. Seizures as adverse events of antibiotic drugs. Neurology 85, 1332-1341. https://doi.org/10.1212/WNL.0000000000002023

Tagliabue, A., Ferraris, C., Uggeri, F., Trentani, C., Bertoli, S., de Giorgis, V., Veggiotti, P., Elli, M., 2017a. Short-term impact of a classical ketogenic diet on gut microbiota in GLUT1 Deficiency Syndrome: A 3-month prospective observational study. Clin. Nutr. ESPEN 17, 33- 
37. https://doi.org/10.1016/j.clnesp.2016.11.003

Tagliabue, A., Ferraris, C., Uggeri, F., Trentani, C., Bertoli, S., de Giorgis, V., Veggiotti, P., Elli, M., 2017b. Short-term impact of a classical ketogenic diet on gut microbiota in GLUT1 Deficiency Syndrome: A 3-month prospective observational study. Clin. Nutr. ESPEN 17, 3337. https://doi.org/10.1016/j.clnesp.2016.11.003

Taher, T.R., Salzberg, M., Morris, M.J., Rees, S., O’Brien, T.J., 2005. Chronic low-dose corticosterone supplementation enhances acquired epileptogenesis in the rat amygdala kindling model of TLE. Neuropsychopharmacology 30, 1610-1616.

https://doi.org/10.1038/sj.npp.1300709

Takanaga, H., Ohtsuki, S., Hosoya, K.-I., Terasaki, T., 2001. GAT2/BGT-1 as a System Responsible for the Transport of $\gamma$-Aminobutyric Acid at the Mouse Blood-Brain Barrier. J. Cereb. Blood Flow Metab. 21, 1232-1239. https://doi.org/10.1097/00004647-20011000000012

Tang, A.T., Choi, J.P., Kotzin, J.J., Yang, Y., Hong, C.C., Hobson, N., Girard, R., Zeineddine, H.A., Lightle, R., Moore, T., Cao, Y., Shenkar, R., Chen, M., Mericko, P., Yang, J., Li, L., Tanes, C., Kobuley, D., Võsa, U., Whitehead, K.J., Li, D.Y., Franke, L., Hart, B., Schwaninger, M., Henao-Mejia, J., Morrison, L., Kim, H., Awad, I.A., Zheng, X., Kahn, M.L., 2017. Endothelial TLR4 and the microbiome drive cerebral cavernous malformations. Nature 545, 305-310. https://doi.org/10.1038/nature22075

Tao, K., Wang, X., 2016. The comorbidity of epilepsy and depression: diagnosis and treatment. Expert Rev. Neurother. 16, 1321-1333. https://doi.org/10.1080/14737175.2016.1204233 Terrone, G., Pauletti, A., Pascente, R., Vezzani, A., 2016. Preventing epileptogenesis: A realistic goal? Pharmacol. Res. 110, 96-100. https://doi.org/10.1016/j.phrs.2016.05.009

Thursby, E., Juge, N., 2017. Introduction to the human gut microbiota. Biochem. J. 474, 18231836. https://doi.org/10.1042/BCJ20160510

Unger, M.M., Spiegel, J., Dillmann, K.-U., Grundmann, D., Philippeit, H., Bürmann, J., Faßbender, 
K., Schwiertz, A., Schäfer, K.-H., 2016. Short chain fatty acids and gut microbiota differ between patients with Parkinson's disease and age-matched controls. Parkinsonism Relat. Disord. 32, 66-72. https://doi.org/10.1016/j.parkreldis.2016.08.019

Valles-Colomer, M., Falony, G., Darzi, Y., Tigchelaar, E.F., Wang, J., Tito, R.Y., Schiweck, C., Kurilshikov, A., Joossens, M., Wijmenga, C., Claes, S., Van Oudenhove, L., Zhernakova, A., Vieira-Silva, S., Raes, J., 2019. The neuroactive potential of the human gut microbiota in quality of life and depression. Nat. Microbiol. 4, 623-632. https://doi.org/10.1038/s41564-0180337-x

van de Wouw, M., Boehme, M., Lyte, J.M., Wiley, N., Strain, C., O’Sullivan, O., Clarke, G., Stanton, C., Dinan, T.G., Cryan, J.F., 2018. Short-chain fatty acids: microbial metabolites that alleviate stress-induced brain-gut axis alterations. J. Physiol. 596, 4923-4944. https://doi.org/10.1113/JP276431

van den Hoogen, W.J., Laman, J.D., ’t Hart, B.A., 2017. Modulation of Multiple Sclerosis and Its Animal Model Experimental Autoimmune Encephalomyelitis by Food and Gut Microbiota. Front. Immunol. 8, 1081. https://doi.org/10.3389/fimmu.2017.01081

Vezzani, A., Balosso, S., Ravizza, T., 2008. The role of cytokines in the pathophysiology of epilepsy. Brain. Behav. Immun. 22, 797-803. https://doi.org/10.1016/j.bbi.2008.03.009

Vieira, É.L.M., de Oliveira, G.N.M., Lessa, J.M.K., Gonçalves, A.P., Oliveira, A.C.P., Bauer, M.E., Sander, J.W., Cendes, F., Teixeira, A.L., 2016. Peripheral leukocyte profile in people with temporal lobe epilepsy reflects the associated proinflammatory state. Brain. Behav. Immun. 53, 123-130. https://doi.org/10.1016/j.bbi.2015.11.016

Walker, S.J., Beavers, D.P., Fortunato, J., Krigsman, A., 2016. A Putative Blood-Based Biomarker for Autism Spectrum Disorder-Associated Ileocolitis. Sci. Rep. 6. https://doi.org/10.1038/srep35820

Werner, F.-M., Coveñas, R., 2015. Review: Classical neurotransmitters and neuropeptides involved in generalized epilepsy in a multi-neurotransmitter system: How to improve the antiepileptic 
effect? https://doi.org/10.1016/j.yebeh.2015.01.038

Wheless, J.W., 2008. History of the ketogenic diet. Epilepsia 49, 3-5.

https://doi.org/10.1111/j.1528-1167.2008.01821.x

Wouters, M.M., Balemans, D., Van Wanrooy, S., Dooley, J., Cibert-Goton, V., Alpizar, Y.A., Valdez-Morales, E.E., Nasser, Y., Van Veldhoven, P.P., Vanbrabant, W., Van der Merwe, S., Mols, R., Ghesquière, B., Cirillo, C., Kortekaas, I., Carmeliet, P., Peetermans, W.E., Vermeire, S., Rutgeerts, P., Augustijns, P., Hellings, P.W., Belmans, A., Vanner, S., Bulmer, D.C., Talavera, K., Vanden Berghe, P., Liston, A., Boeckxstaens, G.E., 2016. Histamine Receptor H1-Mediated Sensitization of TRPV1 Mediates Visceral Hypersensitivity and Symptoms in Patients With Irritable Bowel Syndrome. Gastroenterology 150, 875-887.e9. https://doi.org/10.1053/j.gastro.2015.12.034

Wu, H.-J., Wu, E., 2012. The role of gut microbiota in immune homeostasis and autoimmunity. Gut Microbes 3, 4-14. https://doi.org/10.4161/gmic.19320

Xie, G., Zhou, Q., Qiu, C.-Z., Dai, W.-K., Wang, H.-P., Li, Y.-H., Liao, J.-X., Lu, X.-G., Lin, S.-F., Ye, J.-H., Ma, Z.-Y., Wang, W.-J., 2017. Ketogenic diet poses a significant effect on imbalanced gut microbiota in infants with refractory epilepsy. World J. Gastroenterol. 23, 6164-6171. https://doi.org/10.3748/wjg.v23.i33.6164

Yamamoto, M., Sato, S., Mori, K., Hoshino, K., Takeuchi, O., Takeda, K., Akira, S., 2002. Cutting Edge: A Novel Toll/IL-1 Receptor Domain-Containing Adapter That Preferentially Activates the IFN- $\beta$ Promoter in the Toll-Like Receptor Signaling. J. Immunol. 169, 6668-6672. https://doi.org/10.4049/jimmunol.169.12.6668

Yang, I., Corwin, E.J., Brennan, P.A., Jordan, S., Murphy, J.R., Dunlop, A., 2016. The Infant Microbiome: Implications for Infant Health and Neurocognitive Development. Nurs. Res. 65, 76-88. https://doi.org/10.1097/NNR.0000000000000133

Yatsunenko, T., Rey, F.E., Manary, M.J., Trehan, I., Dominguez-Bello, M.G., Contreras, M., Magris, M., Hidalgo, G., Baldassano, R.N., Anokhin, A.P., Heath, A.C., Warner, B., Reeder, 
J., Kuczynski, J., Caporaso, J.G., Lozupone, C.A., Lauber, C., Clemente, J.C., Knights, D., Knight, R., Gordon, J.I., 2012a. Human gut microbiome viewed across age and geography. Nature 486, 222-227. https://doi.org/10.1038/nature11053

Yatsunenko, T., Rey, F.E., Manary, M.J., Trehan, I., Dominguez-Bello, M.G., Contreras, M., Magris, M., Hidalgo, G., Baldassano, R.N., Anokhin, A.P., Heath, A.C., Warner, B., Reeder, J., Kuczynski, J., Caporaso, J.G., Lozupone, C.A., Lauber, C., Clemente, J.C., Knights, D., Knight, R., Gordon, J.I., 2012b. Human gut microbiome viewed across age and geography. Nature 486, 222-227. https://doi.org/10.1038/nature11053

Yizhar, O., Fenno, L.E., Prigge, M., Schneider, F., Davidson, T.J., O’shea, D.J., Sohal, V.S., Goshen, I., Finkelstein, J., Paz, J.T., Stehfest, K., Fudim, R., Ramakrishnan, C., Huguenard, J.R., Hegemann, P., Deisseroth, K., 2014. Neocortical excitation/inhibition balance in information processing and social dysfunction. Nature 477, 171-178. https://doi.org/10.1038/nature10360

Yurdaydin, C., Walsh, T.J., Engler, H.D., Ha, J.H., Li, Y., Jones, E.A., Basile, A.S., 1995. Gut bacteria provide precursors of benzodiazepine receptor ligands in a rat model of hepatic encephalopathy. Brain Res. 679, 42-8. https://doi.org/10.1016/0006-8993(95)00241-h

Zarrinpar, A., Chaix, A., Yooseph, S., Panda, S., 2014. Diet and Feeding Pattern Affect the Diurnal Dynamics of the Gut Microbiome. Cell Metab. 20, 1006-1017. https://doi.org/10.1016/j.cmet.2014.11.008

Zhang, J.C., Yao, W., Dong, C., Yang, C., Ren, Q., Ma, M., Hashimoto, K., 2017. Blockade of interleukin-6 receptor in the periphery promotes rapid and sustained antidepressant actions: a possible role of gut-microbiota-brain axis. Transl. Psychiatry 7, e1138. https://doi.org/10.1038/tp.2017.112

Zhang, Yifan, Xu, J., Zhang, K., Yang, W., Li, B., 2018. The Anticonvulsant Effects of Ketogenic Diet on Epileptic Seizures and Potential Mechanisms. Curr. Neuropharmacol. 16, 66-70. https://doi.org/10.2174/1570159X15666170517153509 
Zhang, Yunjian, Zhou, S., Zhou, Y., Yu, L., Zhang, L., Wang, Y., 2018. Altered gut microbiome composition in children with refractory epilepsy after ketogenic diet. Epilepsy Res. 145, 163168. https://doi.org/10.1016/j.eplepsyres.2018.06.015

Zheng, P., Zeng, B., Liu, M., Chen, J., Pan, J., Han, Y., Liu, Y., Cheng, K., Zhou, C., Wang, H., Zhou, X., Gui, S., Perry, S.W., Wong, M.-L., Licinio, J., Wei, H., Xie, P., 2019. The gut microbiome from patients with schizophrenia modulates the glutamate-glutamine-GABA cycle and schizophrenia-relevant behaviors in mice. Sci. Adv. 5, eaau8317. https://doi.org/10.1126/sciadv.aau8317

Zmora, N., Suez, J., Elinav, E., 2018. You are what you eat: diet, health and the gut microbiota. Nat. Rev. Gastroenterol. Hepatol. https://doi.org/10.1038/s41575-018-0061-2 
Figure 1 Potential bidirectional pathways involved in the connection between gut-microbiota and epilepsy.

5-HT, serotonin; ACTH, adrenocorticotropic hormone; CRF, corticotrophin-releasing factor; GABA, $\gamma$-aminobutyric acid; HPA, hypothalamic-pituitary-adrenal; IL, interleukin; LPS, lipopolysaccharide; SCFAs, short chain fatty acids.

Figure 2 Supposed pathophysiological cascade in epilepsy involving gut microbiota, peripheral inflammation and neuro-immune response.

$B B B$, blood brain barrier; IL, interleukin; LPS, lipopolysaccharide; TNF- $\alpha$, tumor necrosis factor alpha; VN, vagus nerve.

Figure 3 The ketogenic diet compared to control diet alters relative abundances of selected bacterial taxa from the gut microbiota.

BTBR, BTBR $T^{+} t f / J$ mice; SPF, specific pathogen-free. 
Table 1. Gut microbiota and epilepsy clinical studies

\begin{tabular}{|c|c|c|c|c|c|}
\hline Study design & Diagnosis, (N), Age & $\begin{array}{l}\text { Methodology } \\
\text { /Intervention }\end{array}$ & $\begin{array}{l}\text { Main change in microbiota } \\
\text { composition (genus) }\end{array}$ & Results & References \\
\hline $\begin{array}{l}\text { Observational, } \\
\text { Case-Control } \\
\text { study }\end{array}$ & $\begin{array}{l}\text { Patients with drug-resistant } \\
\text { epilepsy (42), patients } \\
\text { with drug-sensitive epilepsy (49) } \\
\text { and healthy controls (65), age } \\
\text { range } 5 \text { to } 50 \text { years }\end{array}$ & $\begin{array}{l}\text { Faecal samples } \\
\text { 16S rDNA high- } \\
\text { throughput sequencing }\end{array}$ & $\begin{array}{l}\uparrow \alpha \text {-diversity in drug-resistant patients } \\
\leftrightarrow \alpha \text {-diversity drug-sensitive patients } \\
\text { and healthy control } \\
\uparrow \text { rare bacteria in drug-resistant } \\
\text { patients (Clostridium XVIII, Dorea, } \\
\text { Coprobacillus, Ruminococcus, } \\
\text { Akkermansia, Neisseria, Coprococcus) }\end{array}$ & $\begin{array}{l}\text { Clear difference in } \\
\text { microbiota composition } \\
\text { between epileptic drugs- } \\
\text { resistant and sensitive } \\
\text { patients }\end{array}$ & $\begin{array}{l}\text { (Peng et al., } \\
2018 \text { ) }\end{array}$ \\
\hline $\begin{array}{l}\text { Retrospective } \\
\text { Cohort study }\end{array}$ & $\begin{array}{l}\text { Patients with drug-resistant } \\
\text { epilepsy (6), age 10-16 years }\end{array}$ & $\begin{array}{l}\text { Antibiotics treatment } \\
\text { ( } \beta \text {-lactams, } \\
\text { lincosamides or } \\
\text { macrolides })\end{array}$ & n.a. & $\begin{array}{l}\text { Five patients temporarily } \\
\text { seizure-free during antibiotic } \\
\text { treatment until } 2 \text { weeks after } \\
\text { antibiotics cessation }\end{array}$ & $\begin{array}{l}\text { (Braakman } \\
\text { and van } \\
\text { Ingen, 2018) }\end{array}$ \\
\hline $\begin{array}{l}\text { Interventional, } \\
\text { Prospective and } \\
\text { Open-Label } \\
\text { study }\end{array}$ & $\begin{array}{l}\text { Patients with drug-resistant } \\
\text { epilepsy (45), mean age } 44( \pm 13.5) \\
\text { years }\end{array}$ & $\begin{array}{l}\text { 4-months probiotic } \\
\text { supplementations with } \\
\text { Lactobacillus, } \\
\text { Bacteroides } \text { and } \\
\text { Streptococcus spp. }\end{array}$ & n.a. & $\begin{array}{l}\text { Seizures 'number reduction } \\
{[(\geq 50 \% \text { in } 28.9 \% \text { of the }} \\
\text { patients }] \text { and improvement of } \\
\text { Quality of Life score }\end{array}$ & $\begin{array}{l}\text { (Gómez- } \\
\text { Eguílaz et } \\
\text { al., 2018) }\end{array}$ \\
\hline Case-Report & $\begin{array}{l}\text { Patient with Crohn's disease and } \\
\text { epilepsy (120 seizures per year), } \\
20 \text { years old }\end{array}$ & $\begin{array}{l}\text { Faecal microbiome } \\
\text { transplantation }\end{array}$ & n.a. & $\begin{array}{l}\text { After FMT } 20 \text { months } \\
\text { seizure-free period without } \\
\text { concomitant antiepileptic } \\
\text { drugs therapy. }\end{array}$ & $\begin{array}{l}\text { (He et al., } \\
2017)\end{array}$ \\
\hline
\end{tabular}

FMT Faecal microbiome transplantation; spp. Species; n.a. no available 
Table 2. Gut microbiota and epilepsy clinical studies with Ketogenic Diet

\begin{tabular}{|c|c|c|c|c|c|}
\hline Study design & Diagnosis, (N), Age & $\begin{array}{l}\text { Methodology } \\
\text { /Intervention }\end{array}$ & $\begin{array}{l}\text { Main change in microbiota } \\
\text { composition (genus) }\end{array}$ & Results & References \\
\hline $\begin{array}{l}\text { Retrospective } \\
\text { Cohort study }\end{array}$ & $\begin{array}{l}\text { Children with drug-resistant } \\
\text { epilepsy (14) and healthy infants } \\
(30) \text {, mean age } 1.95( \pm 3.10) \text { years }\end{array}$ & $\begin{array}{l}\text { Faecal samples } \\
\text { 16s ribosomal DNA } \\
\text { sequencing/KD for a } \\
\text { week }\end{array}$ & $\begin{array}{l}\text { Drug-resistant patients: } \\
\downarrow \alpha \text {-diversity } \\
\uparrow \text { Firmicutes and Proteobacteria } \\
\text { (Cronobacter) } \\
\downarrow \text { Actinobacteria (Bifidobacterium) } \\
\text { and Bacteroidetes (Bacteroides, } \\
\text { Prevotella) } \\
\text { After KD: } \\
\uparrow \uparrow \text { Bacteroidetes (Prevotella) } \\
\downarrow \text { Proteobacteria (Cronobacter) } \\
\leftrightarrow \text { Firmicutes and Actinobacteria } \\
\text { (Bifidobacterium) }\end{array}$ & $\begin{array}{l}\text { Epileptic drug-resistant } \\
\text { patients differed substantially } \\
\text { from healthy infants and KD } \\
\text { impact substantially the gut } \\
\text { microbiota }\end{array}$ & $\begin{array}{l}\text { (Xie et al., } \\
\text { 2017) }\end{array}$ \\
\hline $\begin{array}{l}\text { Prospective } \\
\text { Observational } \\
\text { study }\end{array}$ & $\begin{array}{l}\text { Patients with Glucose Transporter- } \\
1 \text { Deficiency Syndrome }(6) \text {, age } \\
\text { range } 8-34 \text { years }\end{array}$ & $\begin{array}{l}\text { Faecal samples } \\
\text { real-time qPCR of } \\
\text { selected microbial } \\
\text { taxa analysis/3- } \\
\text { months KD }\end{array}$ & $\begin{array}{l}\text { After KD: } \\
\leftrightarrow \text { Firmicutes, Bacteroidetes and } \\
\text { Proteobacteria ( } \uparrow \text { Desulfobrio })\end{array}$ & $\begin{array}{l}\text { Significant increase in } \\
\text { Desulfovibrio spp. }(\mathrm{p}< \\
0.025) \text {, and a general } \\
\text { microbial depletion after KD } \\
\text { treatment }\end{array}$ & $\begin{array}{l}\text { (Tagliabue et } \\
\text { al., 2017b) }\end{array}$ \\
\hline $\begin{array}{l}\text { Prospective } \\
\text { Observational } \\
\text { study }\end{array}$ & $\begin{array}{l}\text { Patients with drug-resistant } \\
\text { epilepsy (20), age n.a. }\end{array}$ & $\begin{array}{l}\text { Faecal samples } \\
\text { 16S rDNA high- } \\
\text { throughput } \\
\text { sequencing/6-months } \\
\text { KD }\end{array}$ & $\begin{array}{l}\text { After KD in responsive patients: } \\
\downarrow \alpha \text {-diversity } \\
\downarrow \text { Firmicutes and Actinobacteria } \\
\uparrow \text { Bacteroidetes } \\
\leftrightarrow \text { Proteobacteria } \\
\text { After KD in non-responsive patients: }\end{array}$ & $\begin{array}{l}\text { The composition of gut } \\
\text { bacteria differed significantly } \\
\text { after KD compared with } \\
\text { untreated patients. There are } \\
\text { also differences, at family } \\
\text { level, between different } \\
\text { efficacy patients }\end{array}$ & $\begin{array}{l}\text { (Yunjian } \\
\text { Zhang et al., } \\
\text { 2018) }\end{array}$ \\
\hline
\end{tabular}




\begin{tabular}{|c|c|c|c|c|c|}
\hline & & & $\begin{array}{l}\uparrow \text { Clostridiales, Ruminococcaceae, } \\
\text { Rikenellaceae, Lachnospiraceae }\end{array}$ & & \\
\hline $\begin{array}{l}\text { Prospective } \\
\text { Observational } \\
\text { Study }\end{array}$ & $\begin{array}{l}\text { Patients with drug-resistant } \\
\text { epilepsy (20) and healthy parents } \\
\text { as controls (11), age 2-17 years }\end{array}$ & $\begin{array}{l}\text { Faecal samples } \\
\text { Shotgun metagenomic } \\
\text { sequencing/3-months } \\
\text { KD }\end{array}$ & $\begin{array}{l}\downarrow \alpha \text {-diversity in drug-resistant patients } \\
\\
\text { After KD: } \\
\downarrow \alpha \text {-diversity } \\
\\
\uparrow \text { Proteobacteria (Escherichia) } \\
\downarrow \text { Actinobacteria (Bifidobacterium) } \\
\downarrow \text { (Dialister) } \\
\downarrow \text { Eubacterium rectale }\end{array}$ & $\begin{array}{l}\text { The faecal microbiota } \\
\text { changes during KD. The } \\
\text { compositional changes } \\
\text { observed could not be } \\
\text { favorable for gut or overall } \\
\text { health }\end{array}$ & $\begin{array}{l}\text { (Lindefeldt et } \\
\text { al., 2019b) }\end{array}$ \\
\hline
\end{tabular}

KD Ketogenic Diet; spp. Species; n.a. no available 